Article

\title{
Supply and Demand Analysis of Water Resources. Case Study: Irrigation Water Demand in a Semi-Arid Zone in Mexico
}

\author{
Alvaro Alberto López-Lambraño ${ }^{1,2,3, *(1)}$, Luisa Martínez-Acosta ${ }^{1,4}\left(\mathbb{0}\right.$, Ena Gámez-Balmaceda ${ }^{1,5}(\mathbb{D}$, \\ Juan Pablo Medrano-Barboza ${ }^{4}$ (D) John Freddy Remolina López ${ }^{6}$ id and Alvaro López-Ramos 4 \\ 1 Faculty of Engineering, Architecture and Design, Universidad Autónoma de Baja California, \\ Baja California 22860, Mexico; lmartinez18@uabc.edu.mx (L.M.-A.); ena.gamez@uabc.edu.mx (E.G.-B.) \\ 2 Hidrus S.A. de C.V., Ensenada 22760, Mexico \\ 3 Grupo Hidrus S.A.S., Montería 230002, Colombia \\ 4 GICA Group, Faculty of Civil Engineering, Universidad Pontificia Bolivariana Campus Monería, \\ Montería 230002, Córdoba, Colombia; juan.medrano@upb.edu.co (J.P.M.-B.); \\ alvaro.lopezr@upb.edu.co (A.L.-R.) \\ 5 Instituto de Investigaciones Oceanólogicas, Universidad Autónoma de Baja California, \\ Baja California 22860, Mexico \\ 6 ITEM Group, Faculty of Electronic Engineering Universidad Pontificia Bolivariana Campus Montería, \\ Montería 230002, Córdoba, Colombia; john.remolina@upb.edu.co \\ * Correspondence: alopezl@hidrusmx.com; Tel.: +521-442-194-6654 or +521-646-134-5766
}

Received: 27 June 2020; Accepted: 3 August 2020; Published: 5 August 2020

\begin{abstract}
To sustainably use water resources, it is important to quantify water availability in a certain region. Due to climate change, population increase, and economic development, water demand increases continuously. Consequently, the difference between supply and demand of water becomes a significant issue, especially in arid and semi-arid regions. In this research, the Soil and Water Assessment Tool (SWAT) model has been applied to the Guadalupe river basin, to assess supply and demand analysis of water resources in this area, specifically for the irrigation of agricultural crops and municipal uses. From the land use, soil type, and terrain slope maps, 763 Hydrostatic Release Units (HRU) were estimated, distributed in the diverse relief types making up the basin, featured by mountains, hills, plateaus, plains, and valleys. For the crop area, $159 \mathrm{HRU}$ were found with the three slope classification types, where $57 \mathrm{HRU}$ represent $91 \%$ of the cultivated area on slopes, from 0 to $15 \%$, located in the Ojos Negros and Guadalupe Valleys. The Soil Conservation Service method (SCS) was used to estimate the average monthly runoff and soil moisture content. As a result, water resource parameters related to the supply were determined with this, e.g., runoff, aquifer recharge, flow, infiltration, and others. Crop coefficient values $\left(K_{c}\right)$ were used to determine crop evapotranspiration $\left(E T_{c}\right)$, to estimate the water demand of these for each month, using the multi-year monthly average reference evapotranspiration $\left(E T_{o}\right)$ calculated with the SWAT model. Overall good performance was obtained considering average monthly discharges data from the Agua Caliente gauging station. The model was calibrated, modifying the parameters chosen according to sensitivity analysis: SCS curve number, base-flow factor, ground-flow delay, and the threshold for return-flow occurrence. The Soil and Water Assessment Tool-Calibration and Uncertainty Programs SWAT-CUP has different goodness-of-fit indicators for the model e.g., determination coefficient $\left(\mathrm{R}^{2}\right)$, standard deviation of the measured data (RSR), Nash-Sutcliffe coefficient of efficiency (NSE), and others. Multiple iterations were performed, resulting in a ratio between the root mean square error and the standard deviation of the measured data (RSR) of 0.61 , a coefficient of determination $\left(R^{2}\right)$ of 0.70 , and a Nash-Sutcliffe efficiency coefficient (NSE) of 0.63. A supply-demand analysis of the volume generated by the runoff from the basin was performed using the method of estimating useful volume for a reservoir. It is observed in these results that only positive deviations were obtained, implying that runoff in this
\end{abstract}


basin is not enough to meet monthly demand. Finally, the need to establish actions to ensure water management efficiency is highlighted, both for irrigation of agricultural crops and for supply to the region population.

Keywords: Agricultural Water Management; water balance; Soil-Vegetation-Atmosphere

\section{Introduction}

Water is a fundamental natural resource for socio-economic development, food production, and health and sanitation of communities. Similarly, population growth, pollution of water sources, and increasing demand are issues that threaten to exhaust the resource. Therefore, it is necessary to study hydrological cycle variables such as precipitation to be able to quantify liquid availability in a certain region and thus, seek strategies for the comprehensive management of water resources to guarantee socio-economic development, without affecting water availability to future generations [1-3].

These water scarcity issues are more evident in areas with arid and semi-arid climates such as those covering $49 \%$ of the Mexican territory since the distinctive limited rainfall in these regions aggravates the situation [4]. This occurs in the hydrographic basin of the Guadalupe River in Baja California, which has a precipitation regime with a dry season and another one of rains during the winter, recording an average of $254.6 \mathrm{~mm}$ per year [5]. Likewise, this said regime is affected by variability and climate change, contributing to the water resources restriction in the basin [6].

Not only climatic factors aggravate the scarcity issue occurring in the study area but also the demand increase for irrigation water as well, due to the rise in winemaking, the main regional economic activity representing $90 \%$ production of Mexican wines [7]. Since aquifers are the main source to meet water demand for irrigation and supply the community, there is currently a deficit in water volumes due to overexploitation and lack of planning. A situation that negatively affects the regional economy [8].

This shows the need to implement comprehensive management of water resources that promote coordinated development and administration of water, land, and related resources, to equitably maximize the economic results and social assistance without affecting the sustainability of essential ecosystems [9]. Therefore, it is first necessary to determine the resource availability, so that it can be quantified in all the phases and systems (soil, atmosphere, and surface water bodies) of the hydrological cycle, starting from precipitation as the input variable because it is measurable and observable $[10,11]$.

Additionally, this set of phases obeys the water balance equation, which expresses the relationship between inputs, outputs, and internal variations in the soil moisture storage, occurring during a given period. The equation suggests a simple expression; however, its components quantification is usually complex due to lack of direct field measurements, as well as due to spatio-temporal variation thereof $[12,13]$. Therefore, various research has proposed water balance models through estimation of the hydrological cycle components [14-16]; among which those including transfer in the soil-vegetation-atmosphere system, known as Soil-Vegetation-Atmosphere Transfer (SVAT), stand out, which consider this system as a water continuum, made up of a main pathway transporting water between the soil and the atmosphere through the plant, and also consider possible effects of external factors on the physiognomy or physiology of plants $[17,18]$.

In an SVAT system, the rise of the fluid through the plant tissues is due to the gradient of water potential $(\Psi)$, the quantification of the water tendency to flow from one medium to another, passing from greater to lower potential areas (soil $>\Psi$ roots $>\Psi$ stem $>\Psi$ leaves $>$ Tatmosphere). In this journey, various obstacles must be overcome, starting with soil resistance $\left(\mathrm{r}_{\text {soil }}\right)$, since how the soil transfers water to the plants is not homogeneous as it depends on humidity and its properties, influencing the plant retention and water availability. 
Continuing the journey, the water faces root resistance $\left(r_{\text {root }}\right)$, which opposes its passage from the roots to the stem. Likewise, stem resistance $\left(r_{\text {xilem }}\right)$ to the water conduction through the xylem is presented through capillary action to reach the dermis of the leaves. Then, in the leaves. stomata resistance $\left(\mathrm{r}_{\text {leaves }}\right)$ must be overcome so that the plant can carry out the transpiration process. Finally, there is the aerodynamic resistance $\left(r_{a}\right)$, corresponding to the impediment that the wind offers to the exit of water vapor from the epidermis of the leaves to the atmosphere [19-23].

One of the Soil-Vegetation-Atmosphere (SVAT) evaluation models used in various research is the SWAT (Soil Water Assessment Tool) model, developed by the United States Department of Agriculture to analyze the impact of soil management practices on the hydrological cycle, sediment production, and diffusion of chemical substances derived from agronomic practices; and to study parameters related to water quality, such as suspended algae biomass, biological oxygen demand (BOD), and dissolved oxygen concentration; thus allowing discovery of the current and future conditions of the water dynamics from a basin [24].

Recently, the applicability of this model has been verified in multiple scenarios worldwide, managing to develop algorithms for self-irrigation, improve crop yield, analyze precipitation behavior and evaluate water scarcity in a region, and other contributions [25-29]. Nonetheless, most SWAT applications in Mexico have been focused on the center and south of the country, in regions with different climatic conditions from those of the study area, estimating useful parameters in hydrological evaluations and the comprehensive management of the water resource [30-33]. Nonetheless, in the semi-arid zones, the study has been limited to the basins hydrological responses to the different climate change scenarios, and to the study of transboundary basins located between Arizona and Mexico [34,35], without proposing alternatives for decision-making regarding water resource management $[36,37]$.

Because of the above, the performance of the SWAT model applied to the Guadalupe basin is evaluated, located in a semi-arid zone with a Mediterranean climate, determining the significant parameters (Curve Number II (CN2), Based Flow Alpha Factor (ALPHA_BF), Ground Water Dealy time (GW_DELAY) and Threshold Water Depth in the Shallow Aquifer for Flow (GWQMN)) in the calibration and validation of the model results. Subsequently, the model is calibrated from the data obtained from the Agua Caliente gauging station; to later analyze the scarcity problem of water resources by carrying out an evaluation of supply and demand for water in the area.

Consequently, in this research study, water balance of the semi-arid basin from the Guadalupe River was determined through the SWAT model, to assess the resource availability in the region and generate recommendations for the comprehensive management of water resources that could be replicated in regions with similar climatic conditions.

\section{Theory}

The SWAT model is based on the water balance equation (Equation (1) used to determine the input, output, and storage of water in a basin [38], where $S W_{t}$ is the final amount of soil water $(\mathrm{mm})$; $S W_{0}$ is the initial soil water content $(\mathrm{mm})$; $\mathrm{t}$ is the time (days); $R_{\text {day }}$ is the precipitation in the form of rain, snow, dew, or fog, received at the soil surface [24,38,39]; $Q_{\text {surf }}$ is the runoff that refers to the total water that reaches the main streams, composed of surface, sub-surface, and base flow $[24,38,40] ; E_{a}$ is evapotranspiration that involves evaporation from the soil surface, a body of water or that intercepted by vegetation and transpiration from plants $[10,41] ; W_{\text {seep }}$ is the quantity of water that trickles in the soil profile (mm); and $Q_{g w}$ is the quantity of underground flow $[42,43]$.

From Equation (1), change in soil storage $(\Delta S W)$ is estimated, defined as the sheet stored in a soil thickness, and corresponds to the difference between the initial and final content of soil moisture [10]. This way it is established that for any volume and for a certain time, the difference between the water inputs and outputs is conditioned by the stored volume variation.

$$
S W_{t}=S W_{0}+\sum\left(R_{\text {day }}-Q_{\text {surf }}-E_{a}-W_{\text {seep }}-Q_{g w}\right)
$$


Equation (1): Hydrological Model-SWAT.

Likewise, SWAT is a semi-distributed model based on physical principles to quantify the amount of water inside a basin, since it allows consideration of the spatial distribution of precipitation and, in turn, the aspects that affect said distribution from the climatological information of the study area, the physical properties of the soil, topography, vegetation cover and soil management practices $[15,38]$. Therefore, as presented in Equation (1), precipitation is the main input variable for the SWAT model, data gathered from the meteorological stations, and with which the other parameters from the water balance equation, are estimated. From these input parameters, Hydrological Response Units (HRU) are generated, which are scattered areas of the same basin, disconnected from each other, but which maintain homogeneous features such as the slope (which determines the speed of runoff), elevation (precipitation volume varies with height), soil type, vegetation cover, and land use, so these units are expected to exhibit uniform hydrological behavior [30,44,45].

\section{Materials and Methods}

As previously mentioned, the study area corresponds to the Guadalupe river basin located in the northern state of Baja California, between latitudes $31^{\circ} 50^{\prime} \mathrm{N}, 32^{\circ} 16^{\prime} \mathrm{N}$ and longitudes $116^{\circ} 54^{\prime} \mathrm{W}$, $115^{\circ} 52^{\prime} \mathrm{W}$. It is a semi-arid zone with a Mediterranean climate, with an average annual temperature of approximately $16^{\circ} \mathrm{C}$ [46] and average annual precipitation of approximately $254.6 \mathrm{~mm}$ [5]. It has an area of $2390 \mathrm{~km}^{2}$ and is divided into three sub-basins, Ojos Negros located upstream, Guadalupe Valley in the central part, and La Misión sub-basin downstream that empties into the Pacific Ocean (Figure 1).

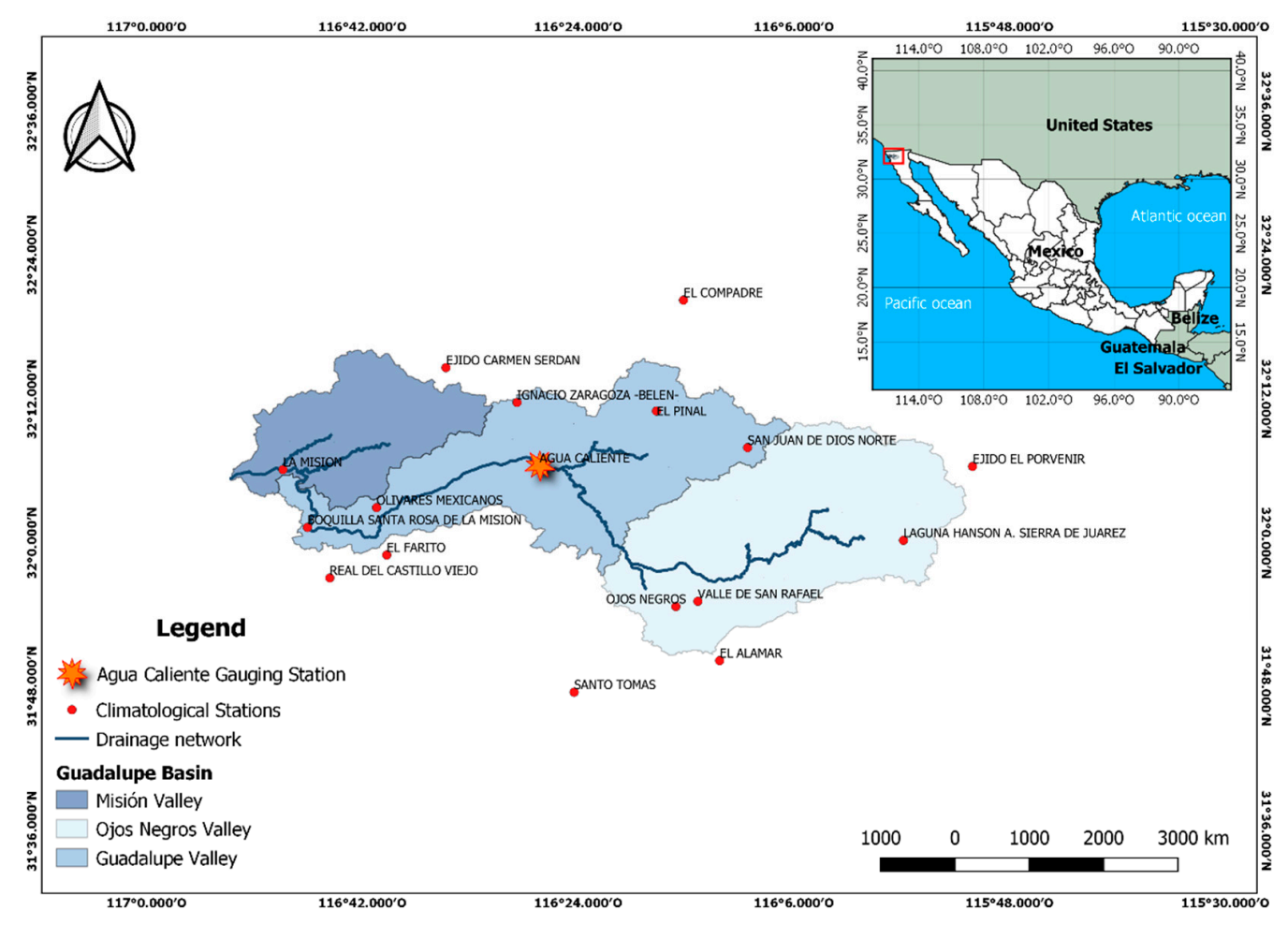

Figure 1. Study Area Location.

Figure 2 shows the structure of the SWAT model that allows use of a Digital Elevation Model (DEM), soil information and meteorological data to simulate the behavior of the components of the hydrological cycle in the study area and to calibrate the model results using the data from a gauging station.

For the modeling, the high-resolution digital elevation model—Light Detection and Ranging or Laser Imaging Detection and Ranging (LiDAR) - from the National Institute of Statistics and Geography (INEGI), corresponding to the Guadalupe river basin, was used as topographic information. 
With a $5 \times 5 \mathrm{~m}$ resolution, where it is recorded that the study area elevations are in the range of 0 to 1283 masl (Figure 3). With this data, the physiographic characteristics of the basin were determined, including main currents, micro-catchment division, and slopes classification (Figure 4).

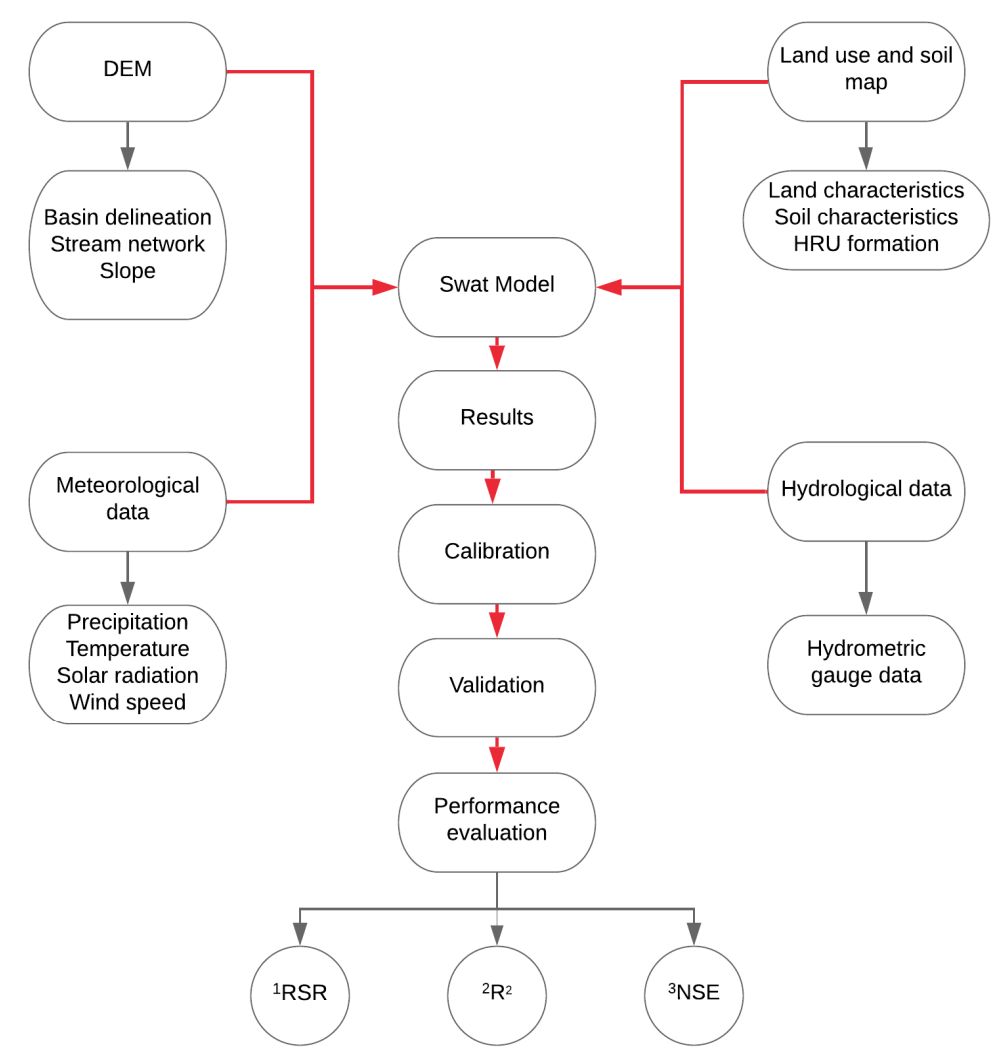

Figure 2. SWAT model structure. ${ }^{1}$ The ratio of the Root-Mean-Square Error (RMSE) to the standard deviation of measured data (RSR); ${ }^{2}$ coefficient of determination $\mathrm{R}^{2}$; and ${ }^{3}$ Nash-Sutcliffe efficiency (NSE).

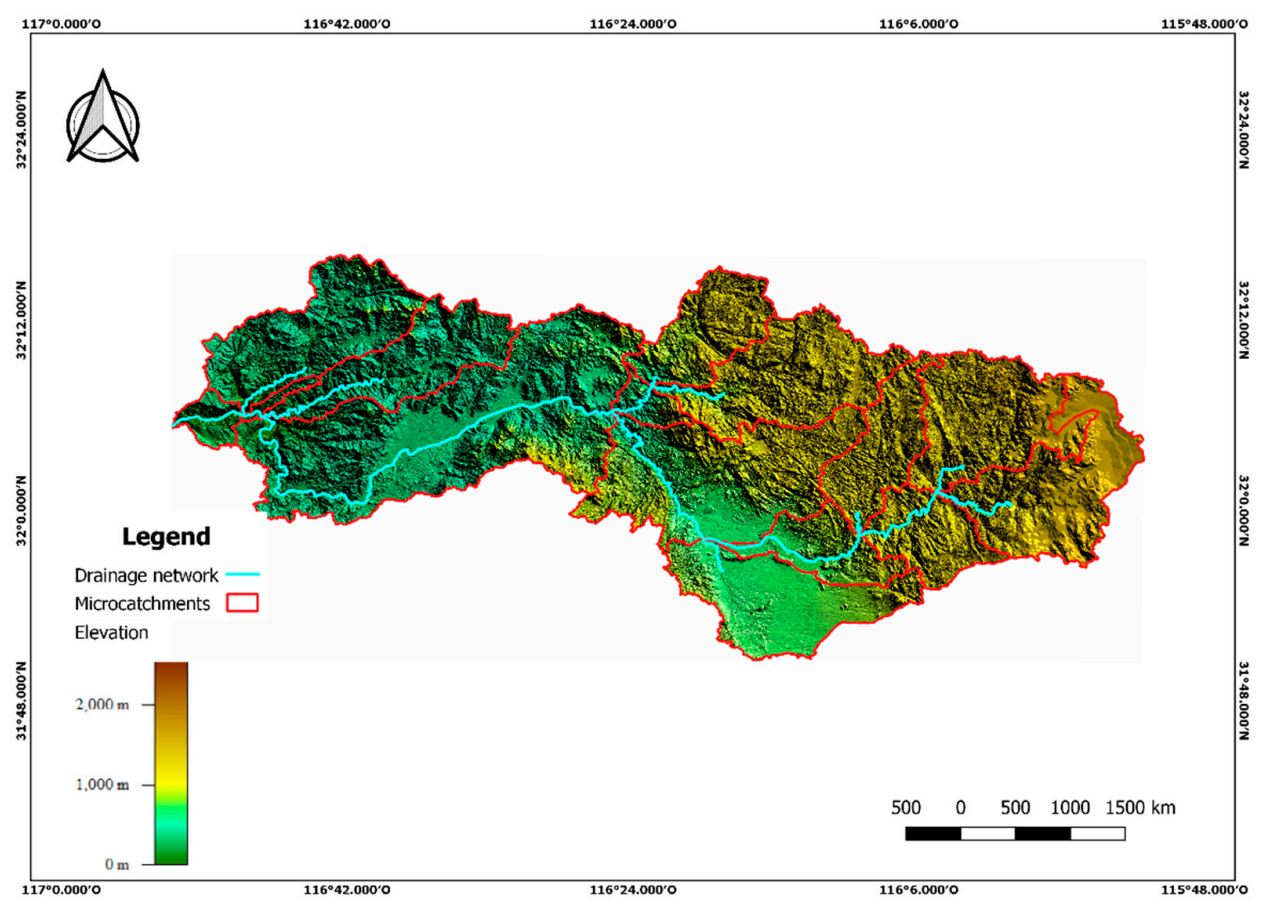

Figure 3. Digital elevation model for Guadalupe river basin. 


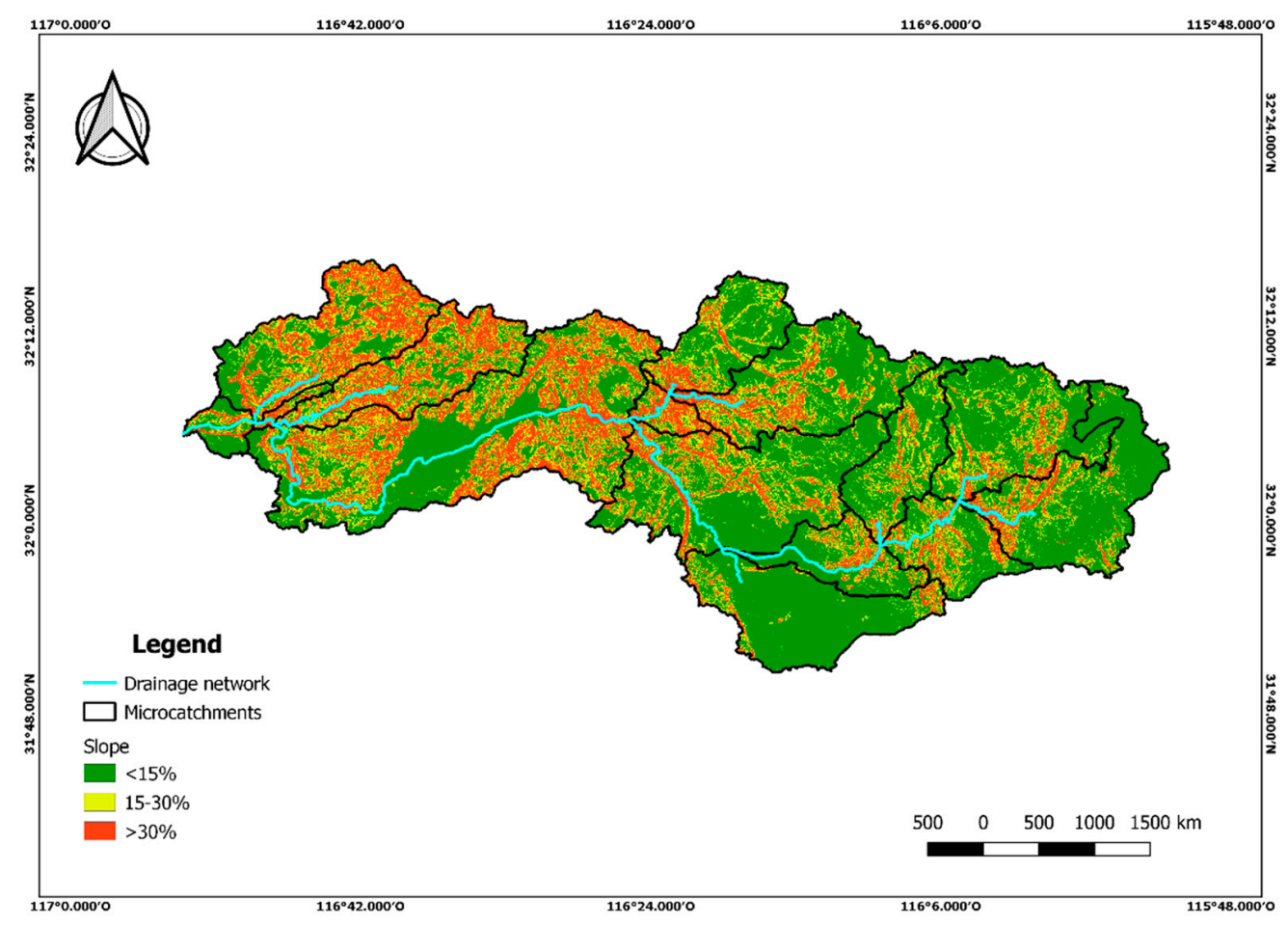

Figure 4. Slope Classification Map.

The maps of use and type of land implemented were prepared from the INEGI Series V digital maps, the INEGI Edaphological chart, scale 1:250,000 [47], and were complemented with the land use data obtained from the State Inventory of Forest and Soils from Baja California [48]. According to Figure 5, it was found that the basin is made up of diverse types of vegetation, where desert scrub can be highlighted with $61 \%$, pine forests with $15 \%$, induced grassland with $11 \%$, and agriculture with 11. Soil composition corresponds to $67 \%$ coarse texture, $32 \%$ medium texture, and $1 \%$ fine texture (Figure 6).

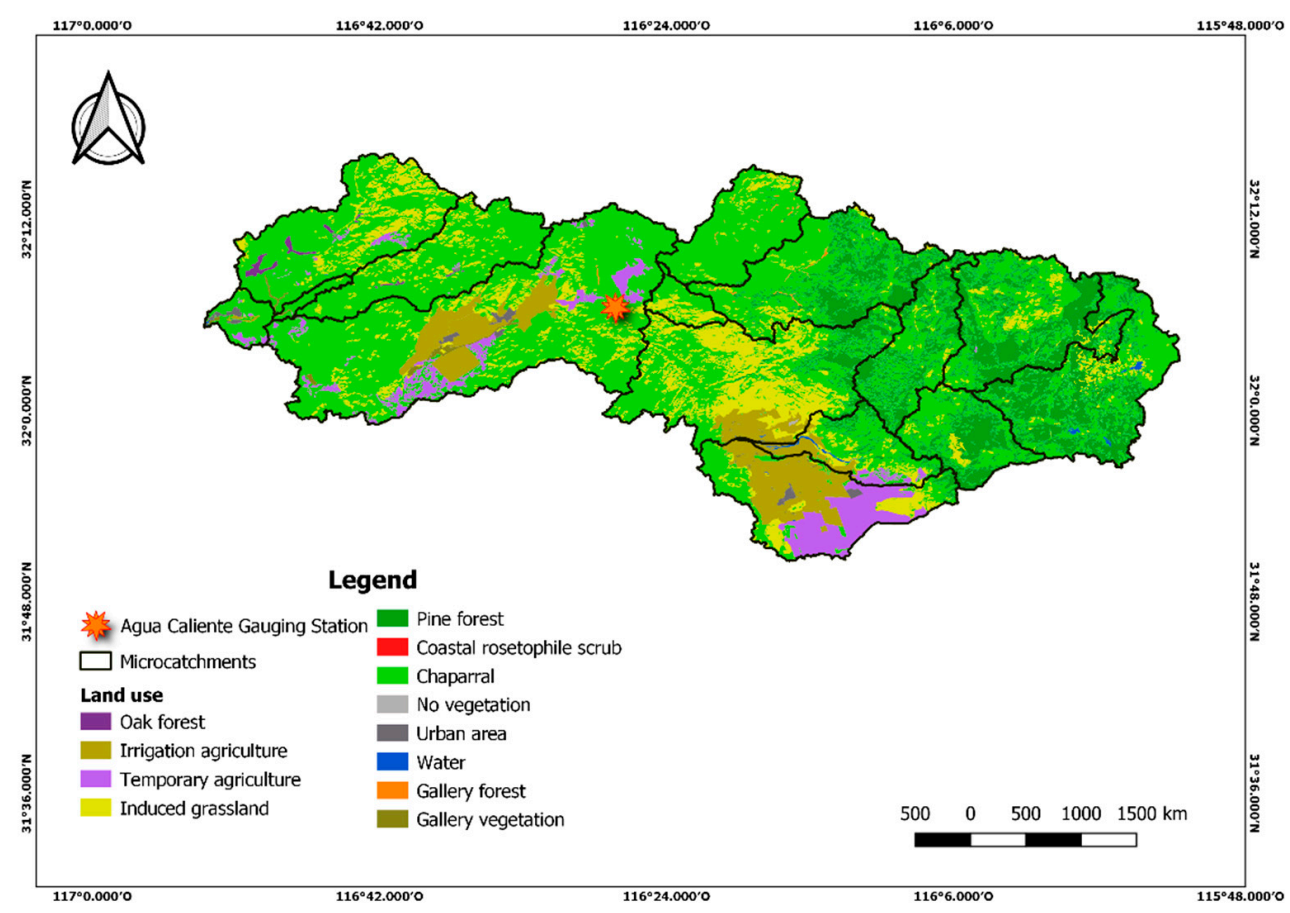

Figure 5. Map of Land Uses. 


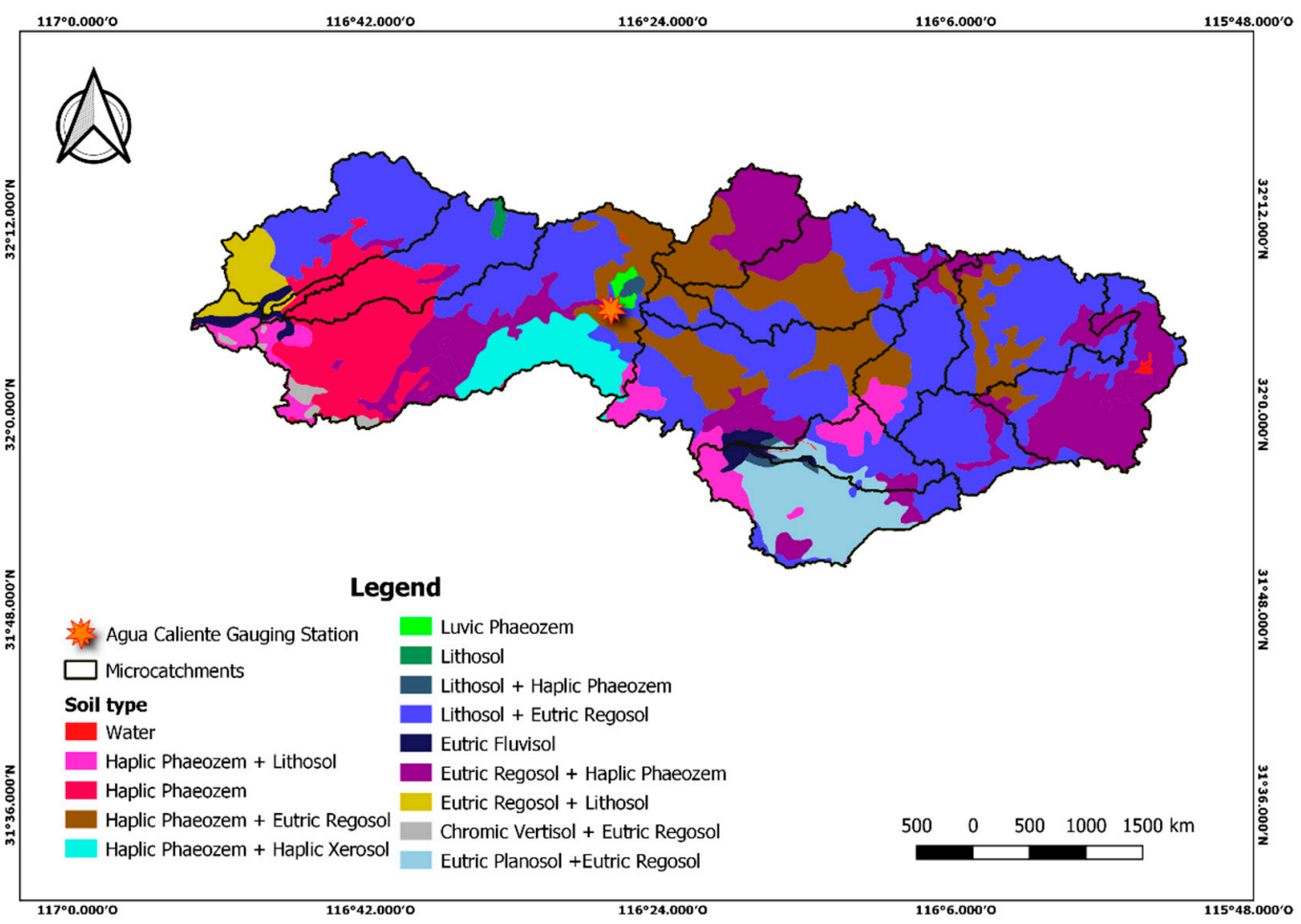

Figure 6. Soil types.

Hydrologic Response Units (HRU) were determined from the described data and use of map algebra, by superimposing the layers of land use, soil type, and slopes, estimating a total of $763 \mathrm{HRU}$ in the basin area. Figure 7 shows the HRU that contemplate the most relevant land uses for this research, corresponding irrigation agriculture, to crops that require water supply from external sources (gravity, dripping, etc.) and temporary agriculture to that which depends on precipitation [49].

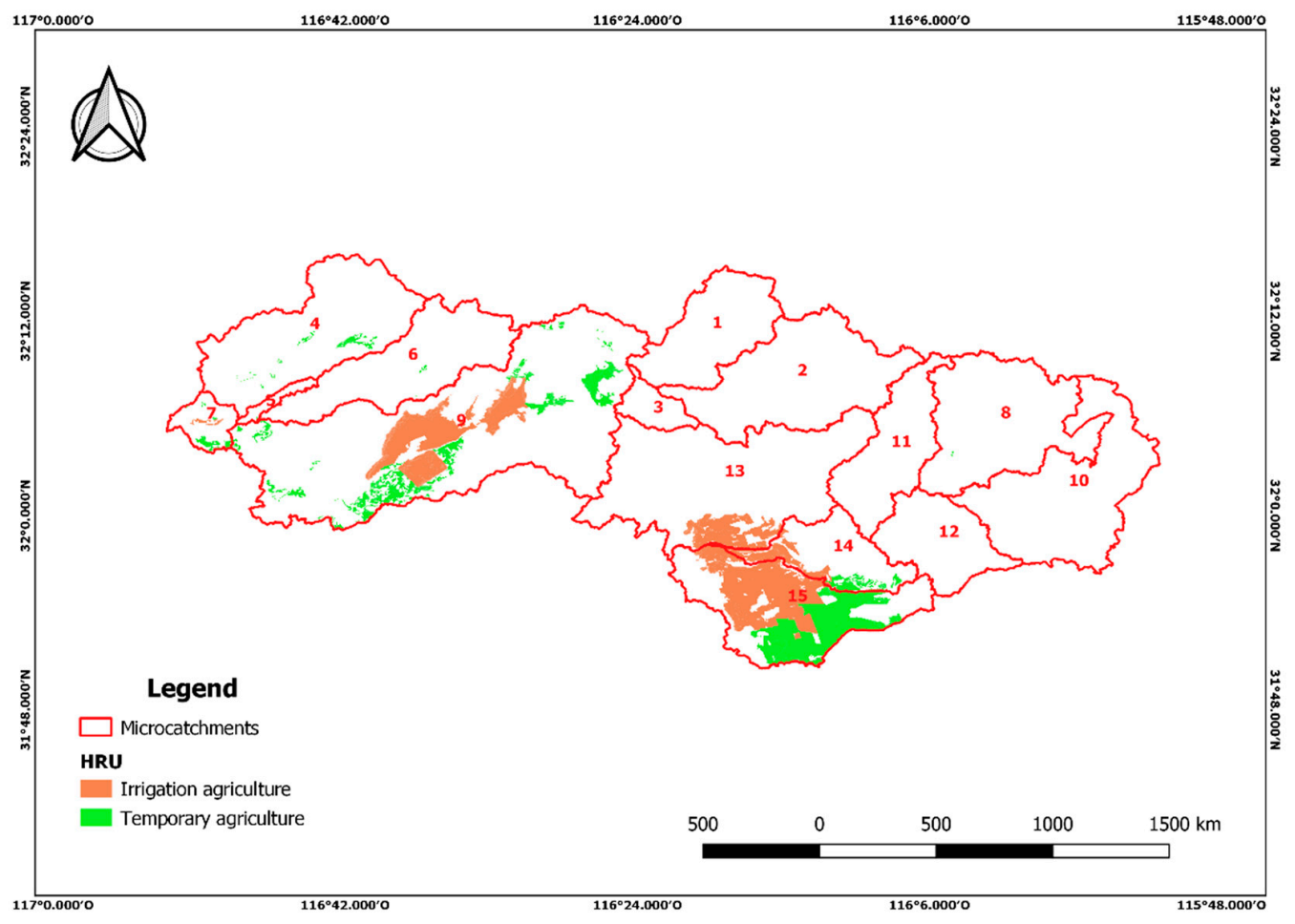

Figure 7. Map of Hydrological Response Units of interest in the Study Area. 
On the other hand, the input variables required for modeling were: precipitation, maximum temperature, minimum temperature, solar radiation, relative humidity and wind speed; and for the climatological analysis, data from 17 stations located in the study area were used (Figure 1), which contain daily historical records for 32 years (1979-2011). It should be mentioned, also, that the records of the weather variables were obtained from the Quick Extraction of Weather Information tool (ERIC III), which contains historical databases from the national meteorological service (SMN); the Climate Computer Project (CLICOM), and from the national water commission (CONAGUA); in addition to the climatological database, The Modern-Era Retrospective analysis for Research and Applications (MERRA), attached to NASA.

From the land use, soil type, and terrain slope maps, (Figures 4-6), 763 HRU were obtained, distributed in the diverse relief types making up the basin, featured by mountains, hills, plateaus, plains, and valleys. For the crop area, 159 HRU were found with the three types of slope classification, where 57 HRU represent $91 \%$ of the cultivated area on slopes from 0 to $15 \%$, located in the Ojos Negros valley and the Guadalupe Valley (Figure 4). The soil type in the crop areas corresponding to planosol, regosol, and phaeozem soils of medium to coarse texture, show a humid hydrometric regime, very good for agricultural production [50]. Moreover, these valleys are settled on a geological basement of alluvial rocks, mainly made up of granular sediment deposits [51], allowing water retention and benefiting crops even more. This water retention is evident only in the rainy months (November to April) probably causing an annual runoff contribution to groundwater. The model results show a decrease in runoff in the months of low rainfall, mainly expected in the sandy soils where the crops, which represent $13 \%$ of the basin area, are located. Nonetheless, due to the rain characteristics in the area, in some years, rains often occur out of season benefiting the surface runoff found with humid soils and therefore, this should be exploited.

Subsequently, once the input data had been organized, the selection of the Penman-Monteith methods for estimating potential evapotranspiration (PET) and the curve number method from the United States Soil Conservation Service [52] to determine runoff, were used; which allowed estimating the basin's monthly water balance. The SCS method is widely used to determine the average monthly runoff and soil moisture content, therefore, with this method, the water resource parameters related to the supply were determined, such as runoff, aquifer recharge, flow, infiltration, and others. Similarly, the Curve Number $(\mathrm{CN})$ considers the relationship between soil cover, type of soil, and the response given in the runoff during a rain event, a situation affected by the previous soil humidity conditions (dry, humid, and normal).

The estimation of the basin water demand was made considering the requirement of the crops and population demand. In the case of crop demand, the crops present in the area were analyzed based on the National Agricultural Survey of the Insituto Nacional de Estadística y Geografía (INEGI by its initial in Spanish) and the general overview document from the Valle de Guadalupe, Baja California, carried out by the Ministry of Agricultural Development [50]. Table 1 lists the crops located in the study and planting areas.

Subsequently, crop coefficient values $\left(K_{c}\right)$ shown in Table 1 for each crop established in the area, were used to determine crop evapotranspiration $\left(E T_{c}\right)$, to estimate the water demand of these, for each month, by means of the multi-year monthly average reference evapotranspiration $\left(E T_{o}\right)$ calculated with the SWAT model. 
Table 1. $\mathrm{K}_{\mathrm{c} \_ \text {ini }}, \mathrm{K}_{\mathrm{c} \_ \text {mid }}$, and $\mathrm{K}_{\mathrm{c} \_ \text {end }}$ from the crops in the study area and their area in the basin.

\begin{tabular}{ccccc}
\hline Crop & $\mathbf{K}_{\mathbf{c} \_ \text {ini }} \mathbf{~}$ & $\mathbf{K}_{\mathbf{c} \_ \text {mid }} \mathbf{2}^{2}$ & $\mathbf{K}_{\mathbf{c} \_ \text {end }}{ }^{\mathbf{3}}$ & Area $\mathbf{~ m}^{\mathbf{2}}$ \\
\hline Alfalfa & 0.40 & 1.15 & 1.15 & 146,401 \\
Oats & & 1.15 & 0.25 & $12,859,268$ \\
Barley & 0.33 & 1.10 & 1.10 & $11,678,949$ \\
Chaparral & 1.00 & 1.00 & 1.00 & $1,466,797,129$ \\
Citrus & 0.90 & 0.90 & 0.9 & $1,132,071$ \\
Stone fruit trees & 0.55 & 1.05 & 1.05 & 383,914 \\
Corn & 0.20 & 1.05 & 1.05 & 13,874 \\
Olives & 0.80 & 0.80 & 0.80 & $26,057,516$ \\
Cucumber & 0.80 & 0.85 & 0.85 & 576,700 \\
Pine tree & 1.15 & 1.15 & 1.15 & $378,010,000$ \\
Tomato & 0.30 & 1.10 & 1.10 & 83,865 \\
Wheat & 0.33 & 1.10 & 1.10 & 103,537 \\
Grape-Wine & 0.45 & 0.80 & 0.80 & $44,050,345$ \\
Pasture & 0.95 & 0.95 & 0.95 & $265,110,000$ \\
Others crops & 0.70 & 0.70 & 0.70 & $5,347,675$
\end{tabular}

${ }^{1}$ Crop coefficient for the initial stage; ${ }^{2}$ Crop coefficient for the mid-season stage; ${ }^{3}$ Crop coefficient for the end of the late season stage; ${ }^{4} \mathrm{FAO}[53]$.

The $K_{c}$ values were gathered from the document of the Information System for the management of irrigation water in Baja California, the entity that made the estimation based on the FAO methodology and by means of the BISms application, with which the irrigation schedules for these crops are gathered [54,55].

The crop evapotranspiration was estimated with Equation (2), considering the crop phases, which were taken from the Instituto Nacional de Investigaciones Forestales Agrícolas y Pecuarias (INIFAP by its initial in Spanish) [56].

$$
E T_{c}=K_{c} E T_{0}
$$

Equation (2). Crop Evapotranspiration.

Where $E T_{c}$ is the crop evapotranspiration in $\mathrm{mm} ; K_{c}$, the crop coefficient, either in the initial, middle, or final stage (with no dimensions); and $E T_{o}$ is the reference evapotranspiration in $\mathrm{mm}$.

Regarding population demand, the demand established by the norm for population consumption in Baja California [57] was used. This was calculated with Equation (3).

$$
Q_{\text {med }}=\frac{D_{w d} \times P}{86400}
$$

Equation (3). Population Water Demand.

Where $Q_{\text {med }}$ is the average daily flow in $1 / \mathrm{s}, D_{\text {wd }}$ is the domestic water demand in 1 per capita per day, $P$ is number of inhabitants and 86,400 is a conversion factor.

Regarding the model calibration and validation, the SWAT-CUP (Calibration and Uncertainty Programs) computer program was used, which belongs to the SWAT family of programs and has 4 different algorithms: Sequential Uncertainty Fitting version 2 (SUFI-2), Generalized Likelihood Uncertainty Estimation (GLUE), applied Parameter Solution (ParaSol) and Particle Swarm Optimization (PSO). The SWAT-CUP was developed by the Swiss Federal Institute of Aquatic Science and Technology and is a public domain program. In this case, the SUFI-2 algorithm was used, based on a Bayesian framework and which determines uncertainties through a sequential and adjustment process. In this algorithm, all sources of uncertainty are considered, such as model input, model structure, model parameters, and measured data. Furthermore, SUFI-2 performs a combined optimization and uncertainty analysis using a global search method and handles many parameters through Latin Hypercube sampling [58,59].

The SWAT-CUP has different goodness-of-fit indicators for the model such as the determination coefficient $\left(R^{2}\right)$, the standard deviation of the measured data (RSR), the Nash-Sutcliffe coefficient of 
efficiency (NSE), and others. In this case, $\mathrm{R}^{2}$ was used as an objective function for calibration. In this way, following the methodology used by Weber and Ocampo [60], a univariate manual pre-adjustment was performed on a set of 9 initially selected parameters, in this way it was possible to detect those parameters that reflect a greater contribution to the improvement of fit statistics. Thus, the 4 parameters selected for model calibration were identified, which are: CN2, ALPHA_BF, GW_DELAY, and GWQMN. It was found that the most sensitive parameter corresponds to the SCS curve number because it is the method used by SWAT to determine surface runoff (Table 2). Once the most sensitive parameters have been chosen, the SUFI-2 algorithm varies these parameters within a predetermined range until there is a good fit with the observed data [58].

Table 2. Initial values for the adjusted parameters and best fitted values after calibration with SUFI-2.

\begin{tabular}{cccc}
\hline Parameters & Description & Range $^{\text {a }}$ & Best Value $^{\text {r }}$ \\
\hline r_CN2 & Initial SCS CNII value & -0.2 to 0.2 & -0.064400 \\
\hline v_ALPHA_BF & Base-flow alpha factor (days) & 0.0 to 1.0 & 0.899000 \\
\hline v_GW_DELAY & Groundwater delay time (days) & 30.0 to 450.0 & 47.220001 \\
\hline v_GWQMN & Threshold water depth in the shallow aquifer for flow (mm) & 0.0 to 2.0 & 1.378000 \\
\hline
\end{tabular}

${ }^{a}$ Default values given by SWAT. v_means the existing parameter value is to be replaced by the given value. r_means the existing parameter value is multiplied by $(1+$ a given value).

\section{Results and Discussion}

First, the hydrological parameters of the SWAT model used for the calibration and simulation uncertainty analysis were selected. The initial and calibrated values of the adjusted parameters are given in Table 2. The data chosen for the calibration correspond to the average monthly flow data for the 1979-1986 period from gauging station 1023 AGUA CALIENTE (Figure 6), as it is the only station with available information on flows within the study area. Multiple iterations were performed, resulting in a relationship between the root mean square error and the standard deviation of the measured data (RSR) of 0.61 , a coefficient of determination $\left(R^{2}\right)$ of 0.70 , and a Nash-Sutcliffe efficiency coefficient (NSE) of 0.63 . Therefore, according to the reviewed literature, the calibration result can be considered satisfactory $[59,61]$. In Figure 8, the comparison of the series of observed data (recorded in the gauging station) with the simulated data after the calibration of the model can be observed.

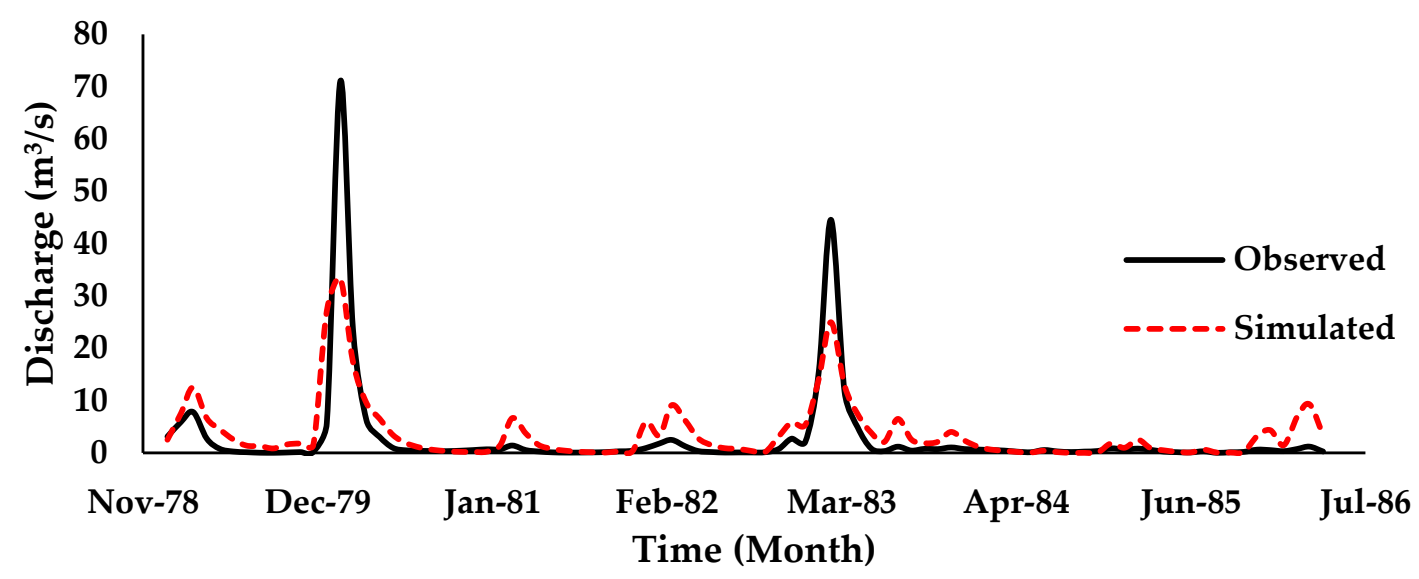

Figure 8. Simulated and observed monthly flow at Agua Caliente Gauging Station by using the SUFI-2 method. 
Figure 9 shows the diagram of the water balance of the study area, where precipitation corresponds to $304.4 \mathrm{~mm}$, evapotranspiration of the plants to $217.7 \mathrm{~mm}$, and runoff to $3.6 \mathrm{~mm}$. Similarly, it is seen that the number of the basin average curve is 35.1 and for this reason, an average percolation of $99.9 \mathrm{~mm}$ is shown, equivalent to $32 \%$ of the average precipitation.

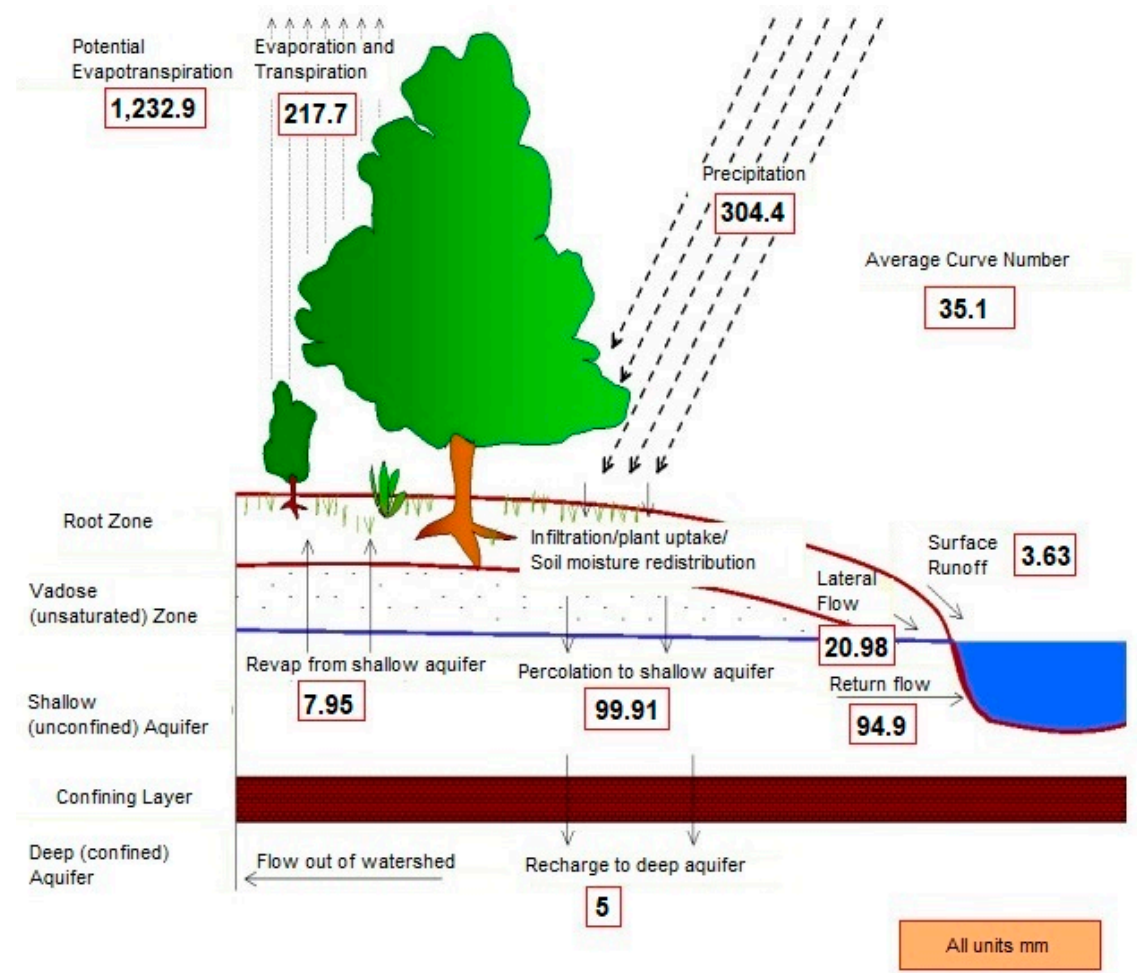

Figure 9. Guadalupe Basin Average Hydrological Balance.

Similarly, according to the results estimated from the water balance shown in Table 3 and Figure 7, the maximum rainfall in the basin occurs from November to March, a period in which $68.35 \%$ of the rains of the year occurs, corresponding to $208.1 \mathrm{~mm}$, with February being the rainiest month with $56.1 \mathrm{~mm}$ and July, the month of least rainfall with $8.7 \mathrm{~mm}$. Similarly, the calculated total runoff, representing the sum of runoff, sub-surface flow, and base flow, minus transmission losses and abstractions, was $105.3 \mathrm{~mm}$, which is $34.59 \%$ of the water precipitated annually. Likewise, it is demonstrated that in the period from November to March, precipitation was $48.9 \mathrm{~mm}$, equivalent to $46.49 \%$ of the total annual runoff. Regarding the calculation of storage, it was found that there is a deficit during the months with the least rainfall (March to July), showing the need to implement measures that allow efficient use of the water available in the study area.

Once the SWAT modeling was performed, and with the results from the $E T_{0}$, the evapotranspiration of the crops, $E T_{\mathcal{c}}$ (Table 4), and the demands of existing agricultural crops and population, were estimated (Table 5).

Table 5 shows that the greatest demand is focused on pine forests, the vegetation from El Chaparral area, and pastures. Although the crops with the highest amount of water demand are vine and olive tree, in line with the economy of the area that is focused on these two agricultural activities, which is the reason the Valle de Guadalupe is recognized for its excellence in wine production. 
Table 3. Average Multi-annual Monthly Water Balance of the Study Area.

\begin{tabular}{|c|c|c|c|c|c|c|c|c|}
\hline Month & $\begin{array}{l}\text { Rainfall } \\
(\mathrm{mm})\end{array}$ & $\begin{array}{l}\text { Evapotranspiration } \\
(\mathrm{mm})\end{array}$ & $\begin{array}{l}\text { Base Flow } \\
(\mathrm{mm})\end{array}$ & $\begin{array}{c}\text { Runoff } \\
(\mathrm{mm})\end{array}$ & $\begin{array}{l}\text { Initial Soil Moisture } \\
\text { (mm) }\end{array}$ & $\begin{array}{l}\text { Final Soil Moisture } \\
(\mathrm{mm})\end{array}$ & $\begin{array}{l}\text { Storage } \\
(\mathrm{mm})\end{array}$ & $\begin{array}{l}\text { Total Runoff } \\
(\mathrm{mm})\end{array}$ \\
\hline January & 53.0 & 17.6 & 5.3 & 1.12 & 52.8 & 58.3 & 5.5 & 10.4 \\
\hline February & 56.1 & 19.6 & 6.0 & 0.76 & 63.1 & 69.3 & 6.1 & 11.4 \\
\hline March & 41.6 & 26.0 & 7.8 & 0.49 & 70.0 & 67.3 & -2.7 & 12.4 \\
\hline April & 22.5 & 29.2 & 7.8 & 0.38 & 62.5 & 56.7 & -5.8 & 10.2 \\
\hline May & 18.2 & 25.9 & 7.8 & 0.13 & 50.4 & 45.7 & -4.7 & 9.6 \\
\hline June & 10.7 & 23.0 & 7.2 & 0.04 & 39.7 & 34.5 & -5.2 & 8.4 \\
\hline July & 8.7 & 15.9 & 6.9 & 0.02 & 30.7 & 29.3 & -1.3 & 7.8 \\
\hline August & 9.9 & 13.2 & 6.4 & 0.03 & 28.6 & 28.5 & -0.0 & 7.2 \\
\hline September & 9.2 & 10.4 & 5.7 & 0.04 & 28.1 & 29.1 & 1.0 & 6.5 \\
\hline October & 17.2 & 10.5 & 5.4 & 0.13 & 30.4 & 33.8 & 3.4 & 6.7 \\
\hline November & 26.0 & 11.0 & 5.0 & 0.22 & 36.3 & 41.8 & 5.5 & 7.1 \\
\hline December & 31.3 & 14.4 & 5.1 & 0.27 & 43.8 & 50.0 & 6.2 & 7.7 \\
\hline Total annual & 304.4 & 217.7 & 76.4 & 3.63 & & & 8.0 & 105.3 \\
\hline
\end{tabular}

Table 4. Average Multi-annual Monthly Rainfall, $E T_{o}$ and $E T_{\mathcal{C}}$ of the crops in the area in $\mathrm{mm}$.

\begin{tabular}{|c|c|c|c|c|c|c|c|c|c|c|c|c|c|c|c|c|c|}
\hline Month & Rainfall & $E T_{o}$ & Grape & Olive & Wheat & Barley & Oats & $\begin{array}{l}\text { Pine } \\
\text { Tree }\end{array}$ & Alfalfa & Corn & Pasture & Citrus & Tomato & Chaparral & $\begin{array}{l}\text { Stone Fruit } \\
\text { Trees }\end{array}$ & Cucumber & $\begin{array}{l}\text { Other } \\
\text { Crops }\end{array}$ \\
\hline January & 53.0 & 17.3 & 7.8 & 13.8 & 5.7 & 5.7 & 19.9 & 19.9 & 6.9 & & 16.4 & 15.6 & & 19.9 & 18.2 & & 12.1 \\
\hline February & 56.1 & 19.4 & 8.7 & 15.5 & 6.4 & 21.3 & 22.3 & 22.3 & 7.7 & & 18.4 & 17.4 & & 22.3 & 20.3 & & 13.6 \\
\hline March & 41.6 & 26.0 & 11.7 & 20.8 & 28.6 & 28.6 & 29.9 & 29.9 & 29.9 & 5.2 & 24.7 & 23.4 & 7.8 & 29.9 & 27.3 & 20.8 & 18.2 \\
\hline April & 22.5 & 29.3 & 13.2 & 23.5 & 32.3 & 32.3 & 33.7 & 33.7 & 33.7 & 5.9 & 27.9 & 26.4 & 8.8 & 33.7 & 30.8 & 24.9 & 20.5 \\
\hline May & 18.2 & 26.0 & 11.7 & 20.8 & 28.6 & 28.6 & 6.5 & 29.9 & 29.9 & 27.3 & 24.7 & 23.4 & 28.6 & 29.9 & 27.3 & 22.1 & 18.2 \\
\hline June & 10.7 & 23.0 & 18.4 & 18.4 & 25.3 & & & 26.4 & 26.4 & 24.1 & 21.8 & 20.7 & 25.3 & 26.4 & 24.1 & 19.5 & 16.1 \\
\hline July & 8.7 & 15.9 & 12.7 & 12.7 & & & & 18.3 & 18.3 & 16.7 & 15.1 & 14.3 & & 18.3 & 16.7 & 13.5 & 11.1 \\
\hline August & 9.9 & 12.6 & 10.1 & 10.1 & & & & 14.5 & 14.5 & 13.3 & 12.0 & 11.4 & 13.9 & 14.5 & 13.3 & 10.7 & 8.8 \\
\hline September & 9.2 & 9.9 & 8.0 & 8.0 & & & & 11.4 & 11.4 & 10.4 & 9.5 & 9.0 & 10.9 & 11.4 & 10.4 & & 7.0 \\
\hline October & 17.2 & 10.3 & 8.2 & 8.2 & & & & 11.8 & 11.8 & 10.8 & 9.8 & 9.3 & 11.3 & 11.8 & 10.8 & & 7.2 \\
\hline November & 26.0 & 11.8 & 9.4 & 9.4 & & 3.9 & 13.5 & 13.5 & 13.5 & 12.4 & 11.2 & 10.6 & 13.0 & 13.5 & 12.4 & & 8.2 \\
\hline December & 31.3 & 14.1 & 11.3 & 11.3 & & 4.6 & 16.2 & 16.2 & 16.2 & 14.8 & 13.4 & 12.7 & & 16.2 & 14.8 & & 9.9 \\
\hline
\end{tabular}


Table 5. Volume of water required for crops and population demand $\mathrm{Mm}^{3}$.

\begin{tabular}{|c|c|c|c|c|c|c|c|c|c|c|c|c|c|c|c|c|c|}
\hline Month & $\begin{array}{l}\text { Grape } \\
\left(\mathrm{Mm}^{3}\right)\end{array}$ & $\begin{array}{l}\text { Olive } \\
\left(\mathrm{Mm}^{3}\right)\end{array}$ & $\begin{array}{l}\text { Wheat } \\
\left(\mathrm{Mm}^{3}\right)\end{array}$ & $\begin{array}{l}\text { Barley } \\
\left(\mathrm{Mm}^{3}\right)\end{array}$ & $\begin{array}{l}\text { Oats } \\
\left(\mathrm{Mm}^{3}\right)\end{array}$ & $\begin{array}{c}\text { Pine } \\
\text { Tree } \\
\left(\mathrm{Mm}^{3}\right)\end{array}$ & $\begin{array}{l}\text { Alfalfa } \\
\left(\mathrm{Mm}^{3}\right)\end{array}$ & $\begin{array}{l}\text { Corn } \\
\left(\mathrm{Mm}^{3}\right)\end{array}$ & $\begin{array}{c}\text { Pasture } \\
\left(\mathrm{Mm}^{3}\right)\end{array}$ & $\begin{array}{l}\text { Citrus } \\
\left(\mathrm{Mm}^{3}\right)\end{array}$ & $\begin{array}{l}\text { Tomato } \\
\left(\mathrm{Mm}^{3}\right)\end{array}$ & $\begin{array}{c}\text { Chaparral } \\
\left(\mathrm{Mm}^{3}\right)\end{array}$ & $\begin{array}{c}\text { Stone Fruit } \\
\text { Trees } \\
\left(\mathrm{Mm}^{3}\right)\end{array}$ & $\begin{array}{l}\text { Cucumbers } \\
\left(\mathrm{Mm}^{3}\right)\end{array}$ & $\begin{array}{l}\text { Other } \\
\text { Crops } \\
\left(\mathrm{Mm}^{3}\right)\end{array}$ & $\begin{array}{l}\text { Dwellers } \\
\left(\mathrm{Mm}^{3}\right)\end{array}$ & $\begin{array}{l}\text { Total } \\
\left(\mathrm{Mm}^{3}\right)\end{array}$ \\
\hline January & 0.343 & 0.361 & 0.001 & 0.067 & 0.256 & 7.520 & 0.001 & & 4.357 & 0.018 & & 29.181 & 0.007 & 0.012 & 0.065 & 0.071 & 42.259 \\
\hline February & 0.384 & 0.404 & 0.001 & 0.249 & 0.286 & 8.420 & 0.001 & & 4.878 & 0.020 & & 32.671 & 0.008 & 0.014 & 0.073 & 0.071 & 47.479 \\
\hline March & 0.515 & 0.542 & 0.003 & 0.334 & 0.384 & 11.297 & 0.004 & 0.0001 & 6.545 & 0.026 & 0.001 & 43.835 & 0.010 & 0.013 & 0.097 & 0.071 & 63.678 \\
\hline April & 0.581 & 0.611 & 0.003 & 0.377 & 0.434 & 12.752 & 0.005 & 0.0001 & 7.388 & 0.030 & 0.001 & 49.480 & 0.012 & 0.011 & 0.110 & 0.071 & 71.866 \\
\hline May & 0.516 & 0.542 & 0.003 & 0.334 & 0.084 & 11.309 & 0.004 & 0.0004 & 6.552 & 0.027 & 0.002 & 43.881 & 0.010 & 0.008 & 0.097 & 0.071 & 63.441 \\
\hline June & 0.809 & 0.479 & 0.003 & & & 9.980 & 0.004 & 0.0003 & 5.782 & 0.023 & 0.002 & 38.725 & 0.009 & 0.006 & 0.086 & 0.071 & 55.980 \\
\hline July & 0.561 & 0.332 & & & & 6.918 & 0.003 & 0.0002 & 4.008 & 0.016 & 0.000 & 26.844 & 0.006 & & 0.060 & 0.071 & 38.818 \\
\hline August & 0.445 & 0.263 & & & & 5.491 & 0.002 & 0.0002 & 3.181 & 0.013 & 0.001 & 21.306 & 0.005 & & 0.047 & 0.071 & 30.826 \\
\hline September & 0.351 & 0.207 & & & & 4.325 & 0.002 & 0.0001 & 2.506 & 0.010 & 0.001 & 16.783 & 0.004 & & 0.037 & 0.071 & 24.297 \\
\hline October & 0.362 & 0.214 & & & & 4.472 & 0.002 & 0.0001 & 2.591 & 0.010 & 0.001 & 17.351 & 0.004 & & 0.039 & 0.071 & 25.117 \\
\hline November & 0.415 & 0.246 & & 0.045 & 0.174 & 5.120 & 0.002 & 0.0002 & 2.966 & 0.012 & 0.001 & 19.868 & 0.005 & & 0.044 & 0.071 & 28.970 \\
\hline December & 0.496 & 0.294 & & 0.054 & 0.208 & 6.122 & 0.002 & 0.0002 & 3.547 & 0.014 & 0.000 & 23.755 & 0.006 & & 0.053 & 0.071 & 34.622 \\
\hline
\end{tabular}


Analogously, knowing the population of 11,871 inhabitants in the Guadalupe basin and its water supply of $200 \mathrm{~L}$ per inhabitant, per day [57]; an average monthly demand of $0.071 \mathrm{Mm}^{3}$ was estimated. Irrigation demand was also calculated from the real evapotranspiration estimated in the modeling and the cultivation coefficient $\left(K_{c}\right)$ [62], obtaining a crop demand (Table 5). Based on these results, a supply-demand analysis of the volume generated by the runoff from the basin was performed using the method of estimating useful volume for a reservoir, shown in Table 6.

Table 6. Average Multi-annual Monthly Volume (runoff) vs. Demand for Guadalupe Basin.

\begin{tabular}{|c|c|c|c|c|c|}
\hline Month & $\begin{array}{c}\text { Volume (Runoff) } \\
\left(\mathrm{Mm}^{3}\right)\end{array}$ & $\begin{array}{c}\text { Accumulated } \\
\text { Volume }\left(\mathrm{Mm}^{3}\right)\end{array}$ & $\begin{array}{l}\text { Total Demand } \\
\left(\mathrm{Mm}^{3}\right)\end{array}$ & $\begin{array}{l}\mathrm{D}-\mathrm{V}^{1} \\
\left(\mathrm{Mm}^{3}\right)\end{array}$ & $\begin{array}{c}\text { Accumulated } \\
\text { Deviations }\left(\mathrm{Mm}^{3}\right)\end{array}$ \\
\hline January & 2.7 & 2.7 & 42.3 & 39.6 & 39.6 \\
\hline February & 1.8 & 4.5 & 47.5 & 45.7 & 85.2 \\
\hline March & 1.2 & 5.7 & 63.7 & 62.5 & 147.8 \\
\hline April & 0.9 & 6.6 & 71.9 & 71.0 & 218.7 \\
\hline May & 0.3 & 6.9 & 63.4 & 63.1 & 281.8 \\
\hline June & 0.1 & 7.0 & 56.0 & 55.9 & 337.7 \\
\hline July & 0.1 & 7.0 & 38.8 & 38.8 & 376.5 \\
\hline August & 0.1 & 7.1 & 30.8 & 30.8 & 407.2 \\
\hline September & 0.1 & 7.2 & 24.3 & 24.2 & 431.4 \\
\hline October & 0.3 & 7.5 & 25.1 & 24.8 & 456.2 \\
\hline November & 0.5 & 8.0 & 29.0 & 28.4 & 484.7 \\
\hline December & 0.7 & 8.7 & 34.6 & 34.0 & 518.7 \\
\hline
\end{tabular}

In these results (Table 6), it is observed that only positive deviations were obtained, which implies that the runoff in this basin is not enough to meet the monthly demand. Also, the value of each deviation indicates the water volume necessary to address it, the reason it can be said that the accumulated runoff would not be enough to meet the demand for a month, proving the deficit occurring in the basin.

It was also identified that between April to September, evapotranspiration is greater than the total precipitation from each month, e.g., in June the actual estimated evapotranspiration was $23 \mathrm{~mm}$ while precipitation was $10.7 \mathrm{~mm}$, a phenomenon that may occur since evapotranspiration is a continuous process that happens day after day, regardless whether precipitation events occur or not.

Subsequently, the supply and demand of the water resource were evaluated by considering the volumes provided by the aquifer. The multi-annual monthly contributions of the aquifer are considered from the water concessions granted by Comisión Nacional del Agua (CONAGUA by its initial in Spanish) in the area and were gathered from previous studies [63].

The results in Table 7 show that there is still a deficit in the resource, where demand exceeds supply.

Table 7. Average Multi-annual Monthly Volume (runoff + underground) vs. Demand for Guadalupe Basin.

\begin{tabular}{|c|c|c|c|c|c|c|}
\hline Month & $\begin{array}{c}\text { Volume } \\
\text { (Runoff) } \\
\left(\mathrm{Mm}^{3}\right)\end{array}$ & $\begin{array}{l}\text { Underground } \\
\text { Volume } \\
\left(\mathrm{Mm}^{3}\right)\end{array}$ & $\begin{array}{l}\text { Accumulated } \\
\text { Volume } \\
\left(\mathrm{Mm}^{3}\right)\end{array}$ & $\begin{array}{c}\text { Total } \\
\text { Demand } \\
\left(\mathrm{Mm}^{3}\right)\end{array}$ & $\begin{array}{c}\text { D-V }{ }^{1} \\
\left(\mathrm{Mm}^{3}\right)\end{array}$ & $\begin{array}{c}\text { Accumulated } \\
\text { Deviations } \\
\left(\mathrm{Mm}^{3}\right)\end{array}$ \\
\hline January & 2.7 & 0.2 & 2.9 & 42.3 & 39.4 & 39.4 \\
\hline February & 1.8 & 0.2 & 4.9 & 47.5 & 45.5 & 84.9 \\
\hline March & 1.2 & 0.4 & 6.4 & 63.7 & 62.1 & 147.0 \\
\hline April & 0.9 & 2.5 & 9.8 & 71.9 & 68.5 & 215.5 \\
\hline May & 0.3 & 2.5 & 12.6 & 63.4 & 60.7 & 276.1 \\
\hline June & 0.1 & 2.5 & 15.2 & 56.0 & 53.4 & 329.5 \\
\hline July & 0.1 & 2.5 & 17.7 & 38.8 & 36.3 & 365.8 \\
\hline August & 0.1 & 2.5 & 20.2 & 30.8 & 28.3 & 394.1 \\
\hline September & 0.1 & 2.5 & 22.8 & 24.3 & 21.7 & 415.9 \\
\hline October & 0.3 & 2.5 & 25.6 & 25.1 & 22.3 & 438.2 \\
\hline November & 0.5 & 0.6 & 26.7 & 29.0 & 27.9 & 466.1 \\
\hline December & 0.7 & 0.4 & 27.7 & 34.6 & 33.6 & 499.7 \\
\hline
\end{tabular}

${ }^{1}$ Demand-Volume. 
It should be noted, as can be seen in Table 8 , that during this period the highest average temperatures and the highest records of solar radiation are shown. This is because these months correspond to the Summer season when the amount of water evaporated from the soil exceeds that transpired by plants, because in most Mediterranean climate species, there is a decrease in transpiration as a strategy to avoid or withstand the stresses that act on the plant due to water deficit, causing a significant variation in optimal living conditions (stress). According to the factor causing it, this can be classified as thermal stress due to extreme temperatures, stress due to high solar radiation, stress due to the scarcity of water available in the soil (water stress), or stress due to pollutants and biotic factors (pests) [18,64-67].

Table 8. Average Multi-annual Monthly Results of Precipitation, Evapotranspiration, Temperature, and Radiation for the HRU.

\begin{tabular}{ccccc}
\hline Month & Rainfall $(\mathbf{m m})$ & Evapotranspiration $\mathbf{( m m})$ & Temperature $\left({ }^{\circ} \mathbf{C}\right)$ & Solar Radiation $\left(\mathbf{M J} / \mathbf{m}^{\mathbf{2}}\right)$ \\
\hline January & 53.0 & 17.6 & 11.9 & 7.7 \\
February & 56.1 & 19.6 & 12.5 & 9.5 \\
March & 41.6 & 26.0 & 13.7 & 12.3 \\
April & 22.5 & 29.2 & 15.9 & 15.4 \\
May & 18.2 & 25.9 & 18.5 & 16.3 \\
June & 10.7 & 23.0 & 21.1 & 16.7 \\
July & 8.7 & 15.9 & 23.3 & 16.3 \\
August & 9.9 & 13.2 & 22.9 & 15.3 \\
September & 9.2 & 10.4 & 20.7 & 13.1 \\
October & 17.2 & 10.5 & 17.3 & 10.4 \\
November & 26.0 & 12.0 & 13.9 & 8.3 \\
December & 31.3 & 14.4 & 11.8 & 7.1 \\
\hline
\end{tabular}

Within the study area (Figure 5), the species present in the chaparral, coastal Rosetophile scrub, and in the oak forests, have developed adaptive physiognomic and physiological strategies to survive. For instance, the Arctostaphylos pungens and Salvia apiana present fuzziness on its leaves that reflect solar radiation, while species such as Adenostoma fasciculatum, Ceanothus greggii, Quercus spp., and Ceanothus spp. can present the ability of curling, wax segregation, size reduction, senescence, and vertical orientation in their leaves [49].

When stress disturbs cultivated plants, production is the first thing affected, as can be seen in vine crops. Water stress decreases the quantity and quality of the harvested grapes, resulting in losses in wine production, proving that plants under stress conditions interrupt vital functions [65].

During the Summer the soil dries decreasing its matrix potential or the water cohesion force to the surface of the soil particles, preventing plants from continuing to absorb water and reaching the point of permanent wilting or cell death, i.e., the water level in the soil is less than the minimum necessary for the plant to absorb it (field capacity). Also, the vegetation generates a readjustment in the osmotic potential, the one that allows water movement due to differences in solute concentrations, without stomatal closure, causing unnecessary water losses, greater absorption by the roots, and increasing the volume necessary for irrigation. Furthermore, if the temperature and solar radiation are very high, the opposite effect occurs, stimulating stomata closure and reducing respiration and photosynthesis. A fact that leads the plant to use its carbon reserves to perform its vital functions, which could affect the sweet taste of fruit and vegetables.

Considering the above and the importance of agricultural activities for the study area, it is necessary to propose alternatives to mitigate the effect of the water deficit on crops. Therefore, the plant should maintain a low evaporation rate and a transpiration level compatible with the water available in the soil, i.e., that transpiration does not exceed the water amount that its roots can absorb, reducing its height, stem, roots, leaf area, and, in cases such as the study area where the water deficit is recurrent, not killing crops. Because of this and given the influence of solar radiation and ambient temperature on the physiology of plants, one of the ways to decrease evapotranspiration is to reduce the amount of 
net radiation that reaches the surface of the crop or soil using alternatives that increase albedos, such as the use of shade nets over the crop, crop residue mulches, or plastic sheeting on the soil surface.

Also, there are other alternatives such as using crops in protected environments, the collection of rainwater in such a way as to guarantee the availability of the resource during a critical period of greatest consumption for plants, i.e., the flowering stage of each species, and the implementation of soil moisture content controls to avoid excess irrigation and runoff leading to the leaching of nutrients such as potassium $(\mathrm{K})$, magnesium $(\mathrm{Mg})$ or Nitrogen $(\mathrm{N})$, and the deficiency of aeration that causes root suffocation and increased disease in crops [68]. Furthermore, implementation of drip irrigation, micro sprinkling, sprinkling, furrow flooding, among other techniques might be sought, so that the available resource can be used most efficiently according to the needs of each crop.

Regarding the water used for irrigation, the water resource must be used during times of maximum rainfall, storing it properly, taking into account that in climates such as the one from the area, evaporation can consume a large part of the stored water if storage structures are kept open and/or exposed to the sun.

It is still worth noting that there are different methods of rainwater use (water harvests) that allow, in one way or another, to optimize irrigation work depending on the crop type and the features of the area, such as micro-basins [69,70], mini runoff catchments, macro catchments and stone lines [71,72], and other rainwater harvesting (RWH) techniques [73]. In the case of the study area, implementation of furrows or blind inlets to the contour of the crops is recommended, since these can reduce the speed of surface drainage, the sediments transport and, in the same way, facilitate the recharge of aquifers to maintain soil moisture and optimize water absorption by plant roots [74-76].

Finally, the need to establish actions to ensure water management efficiency is highlighted, both for irrigation and for supplying the community from the region. Therefore, training programs can be implemented, promoting strategies for administration, self-managing, and of equality regarding the water resource in the basin [77]; identifying the micro-catchments in which it is feasible to build catchment structures that guarantee access to the resource during the months of less rainfall; and preparing and implementing a basin management plan that incorporates the variables of climate change and climate vulnerability.

\section{Conclusions}

The water balance from the Guadalupe basin was estimated, finding evidence that there are conditions favoring deficit in the area, such as low rainfall and high evapotranspiration during different periods of the year. The above is added to the increase in the water demand necessary to meet the community needs and to guarantee crop irrigation. Therefore, promoting a comprehensive water resource management that guarantees agricultural sustainability in addition to the challenges that this activity faces under climate change conditions, require strengthening and development of efficient systems based on new technologies that guarantee crop irrigation with the minimum amount of water required by plants, paying attention to avoiding losses of water or soil moisture due to high temperatures, as well as developing projects for diversification, reconversion, and relocation of crops seeking to only use the existing water availability. Similarly, information systems must be integrated into the area to allow the establishment of accurate forecasts of hydrometeorological events and take actions to counteract them. Governance of water resources must also be reinforced with actions to strengthen agricultural information systems on the availability and allocation of the resource to allow decision-making by following the basin reality. This is done by promoting the organization of the basin users, conducting training, and raising awareness about the efficient use and saving of the water resources. Consequently, investing economic resources in irrigation infrastructure, and rainwater harvesting and use in agriculture, is required, incorporating also, social inclusion indicators that allow the optimization of the amount of water present in the study basin.

In general terms, it was found that the SWAT model is appropriate for the spatio-temporal analysis of the variables that make up the hydrological cycle, allowing establishment of basin water balance. 
Nonetheless, it should be mentioned that the quality of the results will always be subject to information availability. In the case of the Guadalupe basin, it was found that the information related to runoff is scarce due to the few gauging stations installed, so it is expected that for future research a greater amount of hydrometric data will be available for the calibration of the model.

Author Contributions: Conceptualization, A.A.L.-L. and L.M.-A.; methodology, A.A.L.-L., J.P.M.-B., E.G.-B., A.L.-R. and J.F.R.L.; formal analysis, A.A.L.-L., L.M.-A., J.P.M.-B. and A.L.-R.; writing-original draft preparation, A.A.L.-L., L.M.-A., J.P.M.-B., E.G.-B., A.L.-R. and J.F.R.L.; writing-review and editing, A.A.L.-L., L.M.-A., J.P.M.-B., A.L.-R. and J.F.R.L.; visualization, L.M.-A. and J.P.M.-B.; supervision, A.A.L.-L.; project administration, A.A.L.-L., L.M.-A., A.L.-R. and J.F.R.L.; funding acquisition, J.F.R.L. All authors have read and agreed to the published version of the manuscript.

Funding: This research was funded by Universidad Autónoma de Baja California and HIDRUS S.A de C.V, Grupo HIDRUS S.A.S and Universidad Pontificia Bolivariana Campus Montería, the Article Processing Charges (APC) was funded by Universidad Pontificia Bolivariana Campus Montería.

Acknowledgments: The present study was conducted as a research project from the Faculty of Engineering, Architecture and Design, Universidad Autónoma de Baja California and financed by Universidad Pontificia Bolivariana Campus Montería, Universidad Autónoma de Baja California campus Ensenada and Hidrus S.A de C.V.

Conflicts of Interest: The authors declare no conflict of interest.

\section{References}

1. Cole, M.J.; Bailey, R.M.; JCullis, J.D.S.; New, M.G. Water for sustainable development in the Berg Water Management Area, South Africa. South Afr. J. Sci. 2018, 114, 40-50. [CrossRef]

2. Yang, J.; Lei, K.; Khu, S.; Meng, W. Assessment of Water Resources Carrying Capacity for Sustainable Development Based on a System Dynamics Model: A Case Study of Tieling City, China. Water Resour. Manag. 2014, 29, 885-899. [CrossRef]

3. Li, Y.P.; Nie, S.; Huang, C.Z.; McBean, E.A.; Fan, Y.R.; Huang, G.H. An Integrated Risk Analysis Method for Planning Water Resource Systems to Support Sustainable Development of An Arid Region. J. Environ. Inform. 2017, 29, 1-15. [CrossRef]

4. Toro-Guerrero, F.J.; Kretzschmar, T.; Hinojosa-Corona, A. Estimación del balance hídrico en una cuenca semiárida, El Mogor, Baja California, México. Tecnol. Cienc. Agua 2014, 5, 69-81.

5. López-Lambraño, A.; Fuentes, C.; López-Ramos, A.; Pliego-Díaz, M.; López-L, M. Rainfall Series Fractality in the Baja California State. In Recent Advances in Fluid Dynamics with Environmental Applications; Klapp, J., Sigalotti, L.D.G., Medina, A., López, A., Ruiz-Chavarría, G., Eds.; Springer International Publishing: Cham, Switzerland, 2016; pp. 139-152.

6. Vörösmarty, C.; Lettenmaier, D.; Levêque, C.; Meybeck, M.; Pahl-Wostl, C.; Alcamo, J.; Cosgrove, W.; Grassl, H.; Hoff, H.; Kabat, P.; et al. Human transforming the Global Water System. Eos 2004, 85, 509-520. [CrossRef]

7. Andrade, S.G. Cadena de valor económico del vino de Baja California, México. Estud. Front. Nueva Epoca 2015, 16, 97-116.

8. Comisión Nacional del Agua, (CONAGUA). Atlas del agua en México; CONAGUA: Mexico City, Mexico, 2015; pp. 1-135.

9. Soares, D.; Vargas, S.; Nuño, M.R. La gestión de los recursos hídricos: Realidades y perspectivas; Instituto Mexicano de Tecnología del Agua: Guadalajara, Mexico, 2008; ISBN 978-607-7563-05-1.

10. López-lambraño, A.; Fuentes, C.; González, E.; López-Ramos, A. Pérdidas por intercepción de la vegetación y su efecto en la relación intensidad, duración y frecuencia (IDF) de la lluvia en una cuenca semiárida. arti 2017, VIII, 37-56. [CrossRef]

11. Wang Zhang, X.C.; Chongmiao Luo, X.M.L. Concepts of Water Cycle Management for Water Reuse System Design. In Water Cycle Managent; Springer: Heidelberg, Germany, 2015; pp. 7-28. ISBN 978-3-662-45820-4.

12. Ospina-Noreña, J.E.; Domínguez-Ramírez, C.A.; Vega-Rodríguez, E.E.; Darghan-Contreras, A.E.; Rodríguez-Molano, L.E. Analysis of the water balance under regional scenarios of climate change for arid zones of Colombia. Atmosfera 2017, 30, 63-76. [CrossRef] 
13. Candela, L.; Tamoh, K.; Olivares, G.; Gomez, M. Modelling impacts of climate change on water resources in ungauged and data-scarce watersheds. Application to the Siurana catchment (NE Spain). Sci. Total Environ. 2012, 440, 253-260. [CrossRef]

14. Kroes, J.G.; van Dam, J.C. Reference Manual SWAP version 3.0.3. Alterra 2003, 733, 1-211.

15. Arnold, J.G.; Fohrer, N. SWAT2000: Current capabilities and research opportunities in applied watershed modelling. Hydrol. Process. 2005, 19, 563-572. [CrossRef]

16. Kiniry, J.R. General, Process-Oriented Model for Two Competing Plant Species (A). Iowa State Univ. $1992,428$.

17. Quevedo, D. Desarrollo de un Modelo Conceptual Dinámico Suelo-Vegetación para Zonas Aridas y Semiáridas. Ph.D. Thesis, Universidad Politécinica de Valencia, Valencia, Spain, 2010.

18. Valladares, F.; Vilagrosa, A.; Peñuelas, J.; Ogaya, R.; Julio, J.; Corcuera, L.; Sisó, S. CAPÍTULO 6 Estrés hídrico: Ecofisiología y escalas de la sequía. Water 2004, 163-190. [CrossRef]

19. Verhoef, A.; Egea, G. Modeling plant transpiration under limited soil water: Comparison of different plant and soil hydraulic parameterizations and preliminary implications for their use in land surface models. Agric. For. Meteorol. 2014, 191, 22-32. [CrossRef]

20. Gong, J.; Kellomäki, S.; Wang, K.; Zhang, C.; Shurpali, N.; Martikainen, P.J. Modeling $\mathrm{CO}_{2}$ and $\mathrm{CH}_{4}$ flux changes in pristine peatlands of Finland under changing climate conditions. Ecol. Model. 2013, 263, 64-80. [CrossRef]

21. Zhang, B.; Liu, Y.; Xu, D.; Cai, J.; Li, F. Evapotranspiraton estimation based on scaling up from leaf stomatal conductance to canopy conductance. Agric. For. Meteorol. 2011, 151, 1086-1095. [CrossRef]

22. Stoyanova, J.S.; Georgiev, C.G. SVAT modelling in support to flood risk assessment in Bulgaria. Atmos. Res. 2013, 123, 384-399. [CrossRef]

23. Petropoulos, G.P.; North, M.R.; Ireland, G.; Srivastava, P.K.; Rendall, D.V. Quantifying the prediction accuracy of a 1-D SVAT model at a range of ecosystems in the USA and Australia: Evidence towards its use as a tool to study Earth's system interactions. Geosci. Model Dev. 2015, 8, 3257-3284. [CrossRef]

24. Neitsch, S.L.; Arnold, J.G.; Kiniry, J.R.; Williams, J.R. Soil \& Water Assessment Tool Theoretical Documentation Version 2009. Tex. Water Resour. Inst. 2011, 1-647. [CrossRef]

25. Chen, Y.; Marek, G.W.; Marek, T.H.; Brauer, D.K.; Srinivasan, R. Environmental Modelling \& Software Improving SWAT auto-irrigation functions for simulating agricultural irrigation management using long-term lysimeter fi eld data. Environ. Model. Softw. 2018, 99, 25-38. [CrossRef]

26. Guo, T.; Cibin, R.; Chaubey, I.; Gitau, M.; Arnold, J.G.; Srinivasan, R.; Kiniry, J.R.; Engel, B.A. Evaluation of bioenergy crop growth and the impacts of bioenergy crops on streamflow, tile drain flow and nutrient losses in an extensively tile-drained watershed using SWAT. Sci. Total Environ. 2018, 613-614, 724-735. [CrossRef] [PubMed]

27. Goetz, R.U.; Martínez, Y.; Xabadia, À. Efficiency and acceptance of new water allocation rules - The case of an agricultural water users association. Sci. Total Environ. 2017, 601-602, 614-625. [CrossRef] [PubMed]

28. Sinnathamby, S.; Douglas-Mankin, K.R.; Craige, C. Field-scale calibration of crop-yield parameters in the Soil and Water Assessment Tool (SWAT). Agric. Water Manag. 2017, 180, 61-69. [CrossRef]

29. Tuo, Y.; Duan, Z.; Disse, M.; Chiogna, G. Evaluation of precipitation input for SWAT modeling in Alpine catchment: A case study in the Adige river basin (Italy). Sci. Total Environ. 2016, 573, 66-82. [CrossRef] [PubMed]

30. Bautista-Ávalos, D.; Cruz-Cárdenas, G.; Moncayo-Estrada, R.; Silva García, J.T.; Estrada-Godoy, F. Aplicación del modelo SWAT para evaluar la contaminación por fuentes difusas en la subcuenca del lago de Chapala, México. Rev. Int. Contam. Ambient. 2014, 30, 263-274.

31. Sánchez-Galindo, M.; Fernández-Reynoso, D.S.; Martínez-Menes, M.; Rubio-Granados, E.; Ríos-Berber, J.D. Modelo hidrológico de la cuenca del río Sordo, Oaxaca, México, con S W AT. Tecnol. Cienc. Agua 2017, 08, 141-156. [CrossRef]

32. Torres-Benites, E.; Fernández-Reynoso, D.S.; Oropeza-Mota, J.L.; Mejía-Saenz, E. Calibración Del Modelo Hidrológico Swat En La Cuenca. Terra Latinoam. 2004, 22, 437-444.

33. Salgado, A.A.; González, A.R.; Guillermo, J.; Rodríguez, M.; Rivera, M. Segmentacion y balance hidrico en la cuenca del rio Aguanaval utilizando el modelo hidrologico SWAT. Agrofaz 2013, 13, 59-65.

34. Niraula, R.; Norman, L.M.; Meixner, T.; Callegary, J.B. Multi-gauge Calibration for modeling the Semi-Arid Santa Cruz watershed in Arizona-Mexico border area using SWAT. Airsoil Water Res. 2012, 5, 41-57. [CrossRef] 
35. Nie, W.; Yuan, Y.; Kepner, W.; Nash, M.S.; Jackson, M.; Erickson, C. Assessing impacts of Landuse and Landcover changes on hydrology for the upper San Pedro watershed. J. Hydrol. 2011, 407, 105-114. [CrossRef]

36. Esquivel, A.G.; Sánchez, C.I.; Velásquez, V.M.; López, S.A.; López, L.R.; Bueno, H.P. Modelación del escurrimiento en una subcuenca del trópico húmedo de México y su análisis mediante índices de eficiencia predictiva. Agrofaz 2013, 13, 113-118.

37. Molina-Navarro, E.; Trolle, D.; Martínez-Pérez, S.; Sastre-Merlín, A.; Jeppesen, E. Hydrological and water quality impact assessment of a Mediterranean limno-reservoir under climate change and land use management scenarios. J. Hydrol. 2014, 509, 354-366. [CrossRef]

38. Arnold, J.G.; Moriasi, D.N.; Gassman, P.W.; Abbaspour, K.C.; White, M.J.; Srinivasan, R.; Santhi, C.; Harmel, R.D.; Griensven, A.V.; VanLiew, M.W.; et al. Swat: Model Use, Calibration, and Validation. Trans. Am. Soc. Agric. Eng. 2012, 55, 1491-1508.

39. Douglas-Mankin, K.R.; Srinivasan, R.; Arnold, J.G. Soil and Water Assesment Tool (SWAT) Model: Current Developments and Applications. Kans. Agric. Exp. Stn. Manhattankansas. 2010, 53, 1423-1431.

40. Mohammadi, M.; Abdollahi, Z.; Forozanfard, M.; Jamali, S.; Sang, Y.-F. Trend variations of water balance components affected by climate changes (Case study: Atrak river basin, Iran). Azarian J. Agric. 2017, 4, 59-68.

41. Muñoz, E.; Álvarez, C.; Billib, M.; Arumí, J.L.; Rivera, D. Comparison of Gridded and Measured Rainfall Data for Basin-scale Hydrological Studies. Chil. J. Agric. Res. 2011, 71, 459-468. [CrossRef]

42. López Báez, W.; Castro Mendoza, I.; Camas Gómez, R. Servicio ambiental de la reserva de la biósfera El Triunfo, Chiapas, México. Ing. Hidráulica Ambient. 2014, 35, 47-59.

43. dos Reis Pereira, D.; de Quintão Almeida, A.; Martinez, M.A.; Quintão Rosa, D.R. Impactos do desmatamento nos componentes do balanco hídrico de uma bacia na costa leste brasileira. Rev. Bras. De Cienc. Do Solo 2014, 38, 1350-1358. [CrossRef]

44. Flügel, W.-A. Combining GIS with regional hydrological modelling using hydrological response units (HRUs): An application from Germany. Math. Comput. Simul. 1997, 43, 297-304. [CrossRef]

45. Perrin, J.; Ferrant, S.; Massuel, S.; Dewandel, B.; Maréchal, J.C.; Aulong, S.; Ahmed, S. Assessing water availability in a semi-arid watershed of southern India using a semi-distributed model. J. Hydrol. 2012, 460-461, 143-155. [CrossRef]

46. Smith, S.V.; Bullock, S.H.; Hinojosa-Corona, A.; Franco-Vizcaíno, E.; Escoto-Rodríguez, M.; Kretzschmar, T.G.; Farfán, L.M.; Salazar-Ceseña, J.M. Soil erosion and significance for carbon fluxes in a mountainous Mediterranean-climate watershed. Ecol. Appl. 2007, 17, 1379-1387. [CrossRef] [PubMed]

47. Inatituto Nacional de Estadística, Geografía e Informática (INEGI). Diccionario de datos vectoriales Perfiles de suelos. Escala 1:1 000 000-Carta Edafológica; INEGI: Aguascalientes, Mexico, 2011.

48. Comisión Nacional Forestal, CONAFOR Inventario Estatal Forestal y de Suelos Baja California; Secretaría de Medio Ambiente y Recursos Naturales: Tlalpan, Ciudad de Mexico, Mexico, 2014; ISBN 978-607-8383-00-9.

49. Instituto Nacional de Estadística y Geografía, (Mexico). Guía Para la Interpretación de Cartografía Uso del Suelo y Vegetación Escala 1:250 000 Serie V; Instituto Nacional de Estadística y Geografía, INEGI: Aguascalientes, Mexico, 2014; pp. 1-195.

50. Secretaría de Fomento Agropecuario. Panorama general de "Valle de Guadalupe" Baja California. 2014, pp. 1-20. Available online: http://www.oeidrus-bc.gob.mx/oeidrus_bca/pdf/biblioteca/panoramas/ PANORAMA\%20VALLE\%20DE\%20GUADALUPE\%202014.pdf (accessed on 22 July 2020).

51. Sistema Estatal de Protección Civil Baja California Atlas de riesgos de Baja California, USA. Available online: http://www.proteccioncivilbc.gob.mx/Atras/BajaCalifornia.html (accessed on 24 July 2020).

52. SCS Section 4: Hidrology. In National Engineering Handbook; Soil Conservation Service, United States Department of Agriculture: Washington, DC, USA, 1972.

53. Allen, R.G.; Pereira, L.S.; Raes, D.; Smith, M. Evapotranspiración del Cultivo. Guías para la Determinación de los Requerimientos de Agua de los Cultivos; FAO, Ed.; FAO: Roma, Italy, 2006; ISBN 92-5-304219-2.

54. Rodríguez, A. Cálculo de Evapotranspiración del cultivo (ETc) mediante el uso de coeficientes (Kc); Ensenada, Sistema de Información para el Manejjo de Agua de Riego en Baja California. 2014; pp. 1-3. Available online: http://www.simarbc.gob.mx/descargas/Coeficiente\%20del\%20cultivo\%20(Kc).pdf (accessed on 24 July 2020).

55. Snyder, R.L.; Orang, M.; Bali, K.; Eching, S. Manual de Usuario BISms. 2000, p. 6. Available online: http://biomet.ucdavis.edu/irrigation_scheduling/bis/BISms.pdf (accessed on 20 July 2020). 
56. de Carlo, G.R.S.; Salvador, R.C.; Arturo, J.T.; Pedro, F.V.; César, V.S. Necesidades Hídricas de los Principales Cultivos en el Estado de Baja California; Instituto Nacional de Investigaciones Forestales, Agrícolas y Pecuarias: Mexico City, Mexico, 2008; p. 32.

57. CEA Normas Técnicas para Proyectos de Sistemas de Agua Potable y Alcantarillado Sanitario de Baja California. 2014. Available online: http://legismex.mty.itesm.mx/estados/ley-bcn/BC-NT-ProySistAguaPotAlcaSani2014 09.pdf (accessed on 23 July 2020).

58. Abbaspour, K. SWATCalibration and Uncertainty Programs; Swiss Federal Institute of Aquatic Science and Technology: Dübendorf, Switzerland, 2015.

59. Khoi, D.N.; Thom, V.T. Parameter uncertainty analysis for simulating streamflow in a river catchment of Vietnam. Glob. Ecol. Conserv. 2015, 4, 538-548. [CrossRef]

60. Weber, J.F.; Ocampo, S.B. Calibración del modelo hidrológico SWAT para una cuenca de la región serrana de Córdoba (Argentina). Aqua-Lac 2019, 11, 34-53. [CrossRef]

61. Moriasi, D.N.; Arnold, J.G.; Van Liew, M.W.; Bingner, R.L.; Harmel, R.D.; Veith, T.L. Model Evaluation Guidelines for Systematic Quantification of Accuracy in Watershed Simulations. Am. Soc. Agric. Biol. Eng. 2007, 50, 885-900.

62. SAGARPA. Estimación de las Demandas de Consumo de Agua; SAGARPA: Mexico City, Mexico, 2009; p. 33.

63. Comisión Nacional del Agua, CONAGUA. Programa Hídrico Regional Visión 2030. Región HidrológicoAdministrativa I Península de Baja California; Secretaría de Medio Ambiente y Recursos Naturales: Coyoacán, México, 2012; ISBN 978-607-7908-88-3.

64. Schulze, E.-D.; Beck, E.; Müller-Hohenstein, K. Plant Ecology; Springer: New Delhi, IL, USA, 2005; ISBN 978-3-540-20833-4.

65. Begon, M. Ecohydrology: Vegetation Function, Water and Resource Management; Oxford, Blackwell Science: London, UK, 2006; ISBN 0-643-06834-1.

66. Azcon-Bieto, J.; Talón, M. Fundamentos de Fisiología Vegetal; Segunda; McGraw-Hill Interamericana: Murcia, Spain, 2013; ISBN 978-84-481-9293-8.

67. Barceló Coll, J.; Nicolás Rodrigo, G.; Sabater García, B.; Sanchéz Tamés, R. Fisiología Vegetal; Madrid Pirámides: Madrid, Spain, 1987.

68. FAO. Opciones Técnicas Para la Agricultura Familiar en América Latina y el Caribe; FAO: Rome, Italy, 2013.

69. Previati, M.; Bevilacqua, I.; Canone, D.; Ferraris, S.; Haverkamp, R. Evaluation of soil water storage efficiency for rainfall harvesting on hillslope micro-basins built using time domain reflectometry measurements. Agric. Water Manag. 2010, 97, 449-456. [CrossRef]

70. Bello, S.; Michael, O.; Maliki, A.; Azor, A.A. Overview of Rain Water Harvesting (RWH) Systems for Water Conservation. Int. J. Sci. Res. Eng. Dev. 2020, 3, 532-540.

71. Oweis, T.Y. Water Harvesting and Supplemental Irrigation for Improved Water Use Efficiency in Dry Areas; SWIM paper; International Water Management Institute: Colombo, Sri Lanka, 1999; ISBN 978-92-9090-378-9.

72. Galal, K.S. The Efficiency of Rain Water Harvesting Systems in the Lebanese Coastal Zone. Archit. Plan. J. 2020, 26, 1-17.

73. Martínez-Acosta, L.; López-Lambraño, A.A.; López-Ramos, A. Design criteria for planning the agricultural rainwater harvesting systems: A review. Appl. Sci. 2019, 9, 5298. [CrossRef]

74. Ferrer Alessi, V.; Torrero, M.P. Manejo integrado de cuencas hídricas: Cuenca del río Gualjaina, Chubut, Argentina. Bol. Mex. Derecho Comp. 2015, 2015, 615-643. [CrossRef]

75. Napoli, M.; Cecchi, S.; Orlandini, S.; Zanchi, C.A. Determining potential rainwater harvesting sites using a continuous runoff potential accounting procedure and GIS techniques in central Italy. Agric. Water Manag. 2014, 141, 55-65. [CrossRef]

76. Goel, A.K.; Kumar, R. Economic analysis of water harvesting in a mountainous watershed in India. Agric. Water Manag. 2005, 71, 257-266. [CrossRef]

77. Jan, I. Socio-economic determinants of farmers' adoption of rainwater harvesting systems in semi-arid regions of Pakistan. J. Agric. Sci. Technol. 2020, 22, 377-387.

(C) 2020 by the authors. Licensee MDPI, Basel, Switzerland. This article is an open access article distributed under the terms and conditions of the Creative Commons Attribution (CC BY) license (http://creativecommons.org/licenses/by/4.0/). 